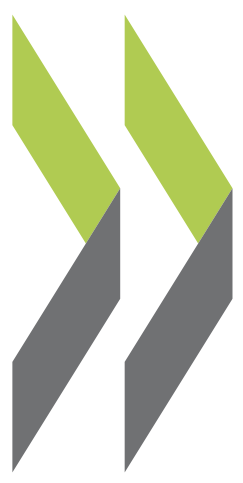

OECD Economics Department Working Papers No. 1212

Reforming the Slovak Public

Lilas Demmou,

Sector Robert Price 
Organisation de Coopération et de Développement Économiques

Organisation for Economic Co-operation and Development

06-May-2015

ECONOMICS DEPARTMENT

English - Or. English

Cancels \& replaces the same document of 28 April 2015

\section{REFORMING THE SLOVAK PUBLIC SECTOR}

ECONOMICS DEPARTMENT WORKING PAPERS No. 1212

\section{By Lilas Demmou and Robert Price}

OECD Working Papers should not be reported as representing the official views of the OECD or of its member countries. The opinions expressed and arguments employed are those of the author(s)

Authorised for publication by Robert Ford, Deputy Director, Country Studies Branch, Economics Department.

All Economics Department Working Papers are available at www.oecd.org/eco/workingpapers

JT03375689

Complete document available on OLIS in its original format

This document and any map included herein are without prejudice to the status of or sovereignty over any territory, to the delimitation of international frontiers and boundaries and to the name of any territory, city or area. 
OECD Working Papers should not be reported as representing the official views of the OECD or of its member countries. The opinions expressed and arguments employed are those of the author(s).

Working Papers describe preliminary results or research in progress by the author(s) and are published to stimulate discussion on a broad range of issues on which the OECD works.

Comments on Working Papers are welcomed, and may be sent to OECD Economics Department, 2 rue André-Pascal, 75775 Paris Cedex 16, France, or by e-mail to eco.contact@oecd.org.

This document and any map included herein are without prejudice to the status of or sovereignty over any territory, to the delimitation of international frontiers and boundaries and to the name of any territory, city or area.

The statistical data for Israel are supplied by and under the responsibility of the relevant Israeli authorities. The use of such data by the OECD is without prejudice to the status of the Golan Heights, East Jerusalem and Israeli settlements in the West Bank under the terms of international law.

\section{(c) OECD (2015)}

You can copy, download or print OECD content for your own use, and you can include excerpts from OECD publications, databases and multimedia products in your own documents, presentations, blogs, websites and teaching materials, provided that suitable acknowledgment of OECD as source and copyright owner is given. All requests for commercial use and translation rights should be submitted to rights@oecd.org 


\title{
ABSTRACT/RÉSUMÉ
}

\author{
Reforming the Slovak Public Sector
}

Improving public sector efficiency can help to meet two conflicting objectives: ensuring fiscal consolidation and maintaining room for growth-friendly spending. However, the public sector lags on the application of e-government and e-procurement, insufficiently prioritizes spending, and suffers from budget fragmentation, lack of coordination between ministries and perceived corruption. The regulatory framework could also be more business friendly and the judicial system more efficient. Boosting public sector efficiency requires broad based reforms. Sequencing will be important for the effectiveness of this comprehensive reform effort, and therefore the government should put an initial emphasis on human resource management and the improvement of administrative capacity.

This Working Paper relates to the 2014 OECD Economic Survey of the Slovak Republic (www.oecd.org/eco/surveys/economic-survey-slovak-republic.htm).

JEL Classification: H11, H2, H3, H5, H7, D73, L5

Keywords: Fiscal framework, VAT gap, public sector, human resource management, judicial system, services regulation, administrative burden.

$* * * * *$

\section{Réformer le secteur public en Slovaquie}

Une amélioration de l'efficience du secteur public peut contribuer à la réalisation de deux objectifs contradictoires : assainir les finances publiques et conserver des marges de manœuvre pour engager des dépenses propices à la croissance. Néanmoins, le secteur public a pris du retard concernant les outils d'administration électronique et les marchés publics dématérialisés. Il ne hiérarchise pas suffisamment ses priorités en matière de dépenses, et pâtit de la fragmentation du budget, du manque de coordination entre ministères et de l'image de corruption qu'il renvoie. Le cadre réglementaire pourrait en outre être plus favorable aux entreprises et le système judiciaire plus efficace. Le renforcement de l'efficience du secteur public passe par des réformes de grande ampleur. Le calendrier de ces réformes d'envergure est un élément important de leur efficacité, de sorte que le gouvernement devrait mettre l'accent au départ sur la réforme de la gestion des ressources humaines et l'amélioration des capacités administratives.

Ce document de travail se rapporte à l'Étude économique de l'OCDE 2014 sur la République Slovaque (www.oecd.org/fr/eco/etudes/etude-economique-republique-slovaque.htm).

Classification JEL : H11, H2, H3, H5, H7, D73, L5

Mots clés : Cadre fiscal, écart de TVA, secteur public, gestion des ressources humaines, système judiciaire, regulation des services, charge administrative. 


\section{TABLE OF CONTENTS}

Reforming the Slovak public sector

Budget planning efficiency: anchoring the budget process in longer-term perspective ............................

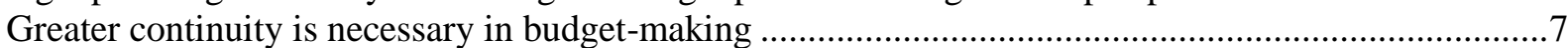

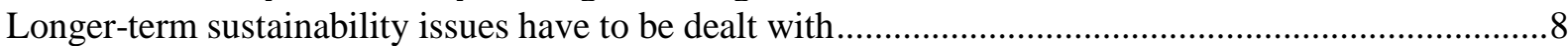

Allocative efficiency: spending should address priorities more effectively .......................................10

Spending patterns do not reflect the priorities of a catching-up economy .............................................10

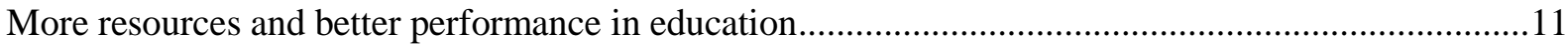

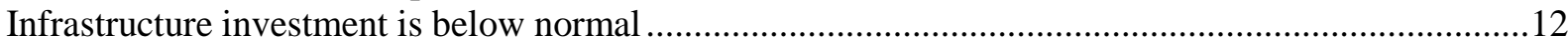

Government investment in R\&D could be selectively increased ......................................................13

Institutional efficiency: reducing budget fragmentation and improving co-ordination ............................14

Towards a more holistic approach to policy making..........................................................................14

Getting the most out of EU structural funds is a key co-ordination challenge......................................15

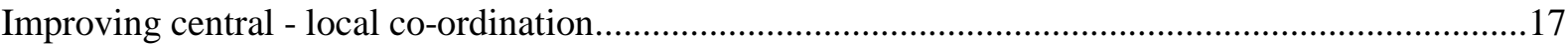

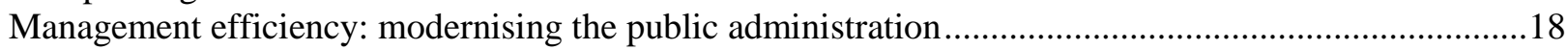

Results-oriented budgeting would improve administrative efficiency ..........................................18

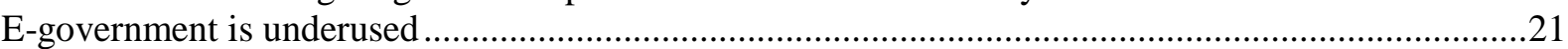

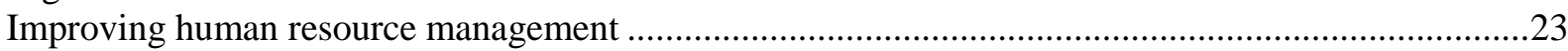

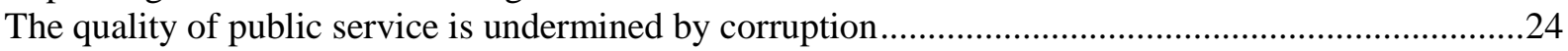

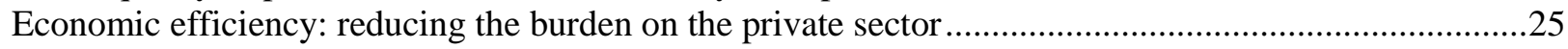

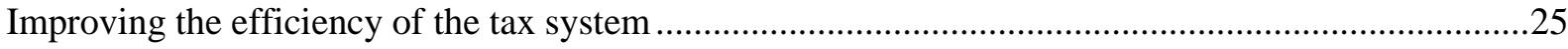

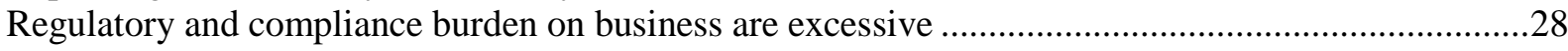

An inefficient justice system is holding back the economy …..............................................................

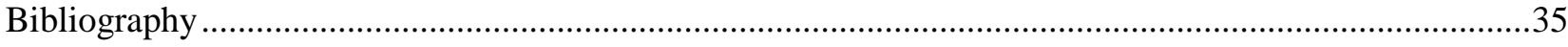

\section{Tables}

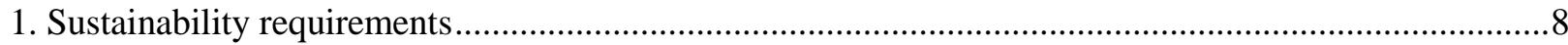

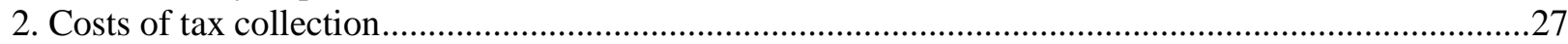

\section{Figures}

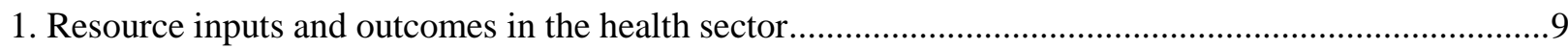

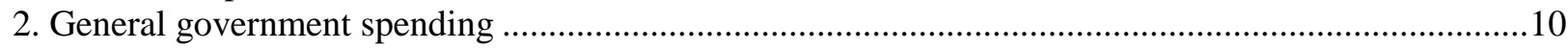

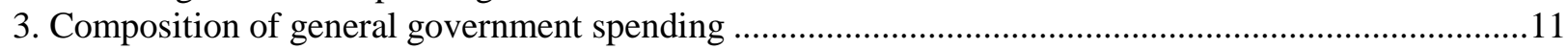

4. Education outcomes in secondary education and spending per student ............................................12

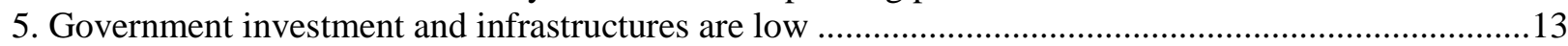

6. Resource inputs and performance in government general services ..............................................19

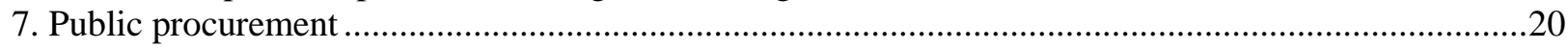

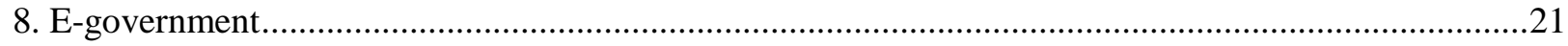

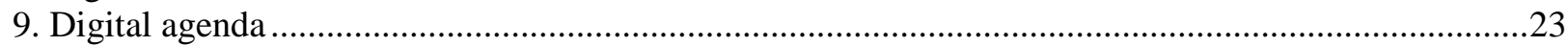

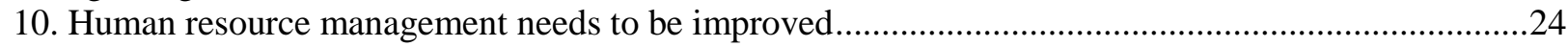

11. Extent of bribery and corruption perception in selected areas .........................................................25

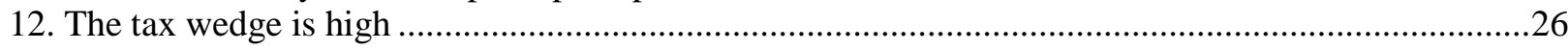

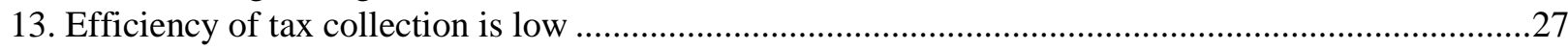




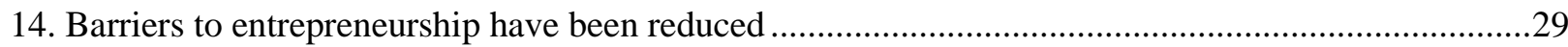

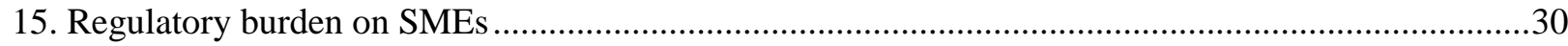

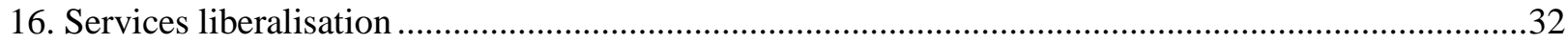

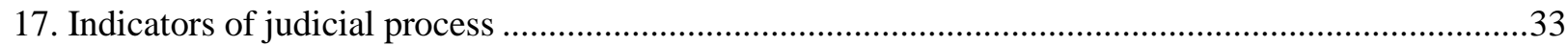

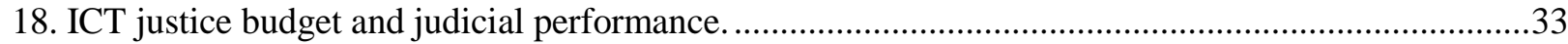

\section{Boxes}

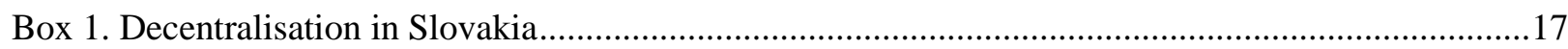

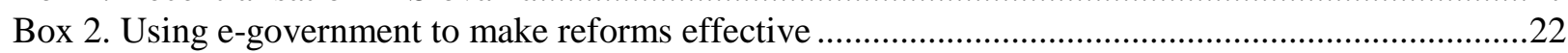

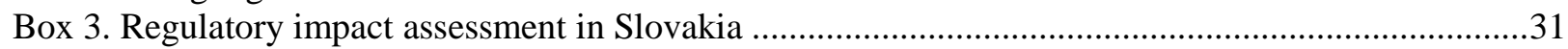

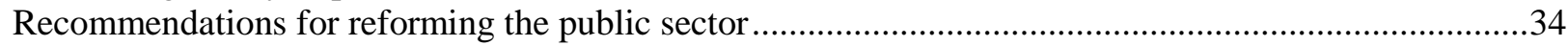


ECO/WKP(2015)30 
ECO/WKP(2015)30

\title{
REFORMING THE SLOVAK PUBLIC SECTOR
}

\author{
By Lilas Demmou and Robert W.R. Price ${ }^{1}$
}

Improving public sector efficiency is rightly among the key government priorities. Two of the five key areas in the National Reform Programme (NRP) 2011-14 relate to "continued fiscal consolidation aimed at economic growth" and the "modernisation of the public administration". These two objectives are complementary. The need for continued fiscal consolidation can stimulate government efficiency in all its dimensions: budget planning, programme allocation and prioritisation of resources, and administrative and managerial effectiveness. In that way, welfare reducing programme cuts or tax increases can be avoided. At the same time, the public sector should become an instrument for stronger, more inclusive and diversified growth, which, by helping to strengthen the domestic production - and tax - base, also adds to longer-run budget sustainability.

The structure of the chapter is as follows. In the first section, the issues of budget planning efficiency are discussed, the integration of longer-term budget constraints into short-term budget decision-making being critical to sustainability. In the second section, allocative efficiency is discussed in terms of the spending priorities of a catching-up economy. The third section then discusses issues of institutional coordination determining the ability to address priorities ex ante, including issues related to the allocation of structural funds. The fourth section looks at the potential for efficiency gains as the administration is modernised. The final section addresses the issue of tax, regulatory and administrative burdens imposed on the private sector, the efficiency of the interface between public and private sectors being crucial to growth and employment performance.

\section{Budget planning efficiency: anchoring the budget process in longer-term perspective}

\section{Greater continuity is necessary in budget-making}

The efficiency of the budget planning framework is a key determinant of public sector efficiency, as it can ensure continuity, consistency and stability in policy making. Fiscal rules are important here. In response to the requirements of the Treaty on Stability, Coordination and Governance, Slovakia introduced a balanced structural budget rule in November 2013, with the commitment to decrease the structural budget deficit to $0.5 \%$ of GDP by 2017 . This is a more demanding sustainability constraint than the criterion of stabilising debt at the $60 \%$ debt ceiling (Table 1). According to the 2014 Budget - which expects the structural budget deficit to increase to around 4\% of GDP in 2014 - further structural measures worth 3.5\% of GDP will be needed by 2017 to meet the $0.5 \%$ target. While a balanced structural budget may not be optimal for a catching up economy like Slovakia, where public investment is crucial to growth, from a financial market perspective it helps to put the debt ratio on a downward path (towards the upper limit of 50\% by 2027) and gives more room for automatic stabilisers to operate than is currently available under the operational debt ceilings. However, the credibility of the structural budget target has yet to be

1. Lilas Demmou was acting Head of the Slovak Desk in the Economics Department of the OECD in Paris and Robert Price was consultant. This paper was originally produced for the 2014 OECD Economic Survey of the Slovak Republic and published in November 2014, under the authority of the Economic and Development Review Committee (EDRC). It has benefited at an early stage from contributions from Artur Radziwill when he was working at the OECD and Yana Vaziakova. The authors are grateful to Bob Ford, Alvaro Pereira, and Andreas Wörgötter for their guidance. They would like to thank Bert Brys, Richard Highfield, Jonathan Leigh Pemberton, Pierre Leblanc and Jares Martin (Centre for Tax Policy and Administration), Filippo Cavassini and Daniel Trnka (Public Governance and Territorial Development Directorate), the Slovak authorities and members of the EDRC for valuable comments and discussions. The authors would also like to thank Seung-Hee Koh for statistical research. Technical preparation was provided by Heloise Wickramanayake and Mercedes Burgos. 
fully established which may, in part, be due to the fact that the sources of the expenditure cuts have yet to be identified and neither have the means of maintaining structural balance through to 2027 .

Table 1. Sustainability requirements

\begin{tabular}{|c|c|c|c|c|c|c|c|c|c|c|c|c|}
\hline & \multirow{2}{*}{$\begin{array}{c}\text { Consolidation }^{1} \\
2010-13\end{array}$} & \multicolumn{2}{|c|}{$\begin{array}{c}\text { Consolidation } \\
\text { over } 2016-30 \text { to } \\
\text { stabilise debt at } \\
60 \%{ }^{2}\end{array}$} & \multicolumn{3}{|c|}{ Financial balances $^{3}$} & \multicolumn{3}{|c|}{$\begin{array}{l}\text { Gross financial } \\
\text { liabilities }^{4}\end{array}$} & \multicolumn{3}{|c|}{$\begin{array}{l}\text { Long-term real } \\
\text { interest rates }\end{array}$} \\
\hline & & Average & Peak & 2013 & 2020 & 2030 & 2013 & 2020 & 2030 & 2013 & 2020 & 2030 \\
\hline $\begin{array}{l}\text { Slovak } \\
\text { Republic }\end{array}$ & 4.5 & 1.1 & 1.6 & -2.8 & -1.3 & -1.1 & 59 & 62 & 60 & 2.0 & 2.0 & 2.2 \\
\hline Euro Area & 3.6 & 1.4 & 2.6 & -3.0 & 1.7 & 0.2 & 107 & 92 & 61 & 1.6 & 2.2 & 2.1 \\
\hline OECD & 3.2 & 2.1 & 3.8 & -4.9 & -0.6 & 0.1 & 109 & 103 & 77 & 1.1 & 2.6 & 2.5 \\
\hline
\end{tabular}

1. Consolidation is measured as the change in the underlying primary balance, as a percentage of potential GDP.

2. Over the projection period, countries with gross government debt ratios in excess of $60 \%$ of GDP are assumed to gradually reduce debt to this level, whereas other countries stabilise debt ratios at their current levels. Consolidation requirement from 2015 to achieve these objectives are measured as the difference between the underlying primary balance in 2015 and its average or its peak over the period to 2030 (or until the debt ratio stabilises).

3. General government fiscal surplus (+) or deficit (-) as percentage of GDP.

4. Includes all financial liabilities as defined by the system of national accounts (where data availability permits) and covers the general government sector, which is a consolidation of central, state and local governments and the social security sector. The definition of gross debt differs from the Maastricht definition used to assess EU fiscal positions.

5. Nominal 10-year government bonds adjusted by the GDP deflator.

Source: OECD Economic Outlook 95 Long-Term Database.

Anchoring expectations that medium-term consolidation goals will be fulfilled, while also allowing for short-term fiscal flexibility, requires reinforcement of the medium-term budgetary framework. Credibility is currently compromised by the fact that in the past there has been substantial slippage from the long-run adjustment path due to a failure to exert discipline and run an adequate surplus during recovery years (Horvath and Odor, 2009). Safeguards against a recurrence of this tendency to fiscal slippage need to be put in place. While the debt ceiling rules and the establishment of a Fiscal Council help, debt controls and sanctions are very much ex post devices which only come into play when rules have been breached and confidence needs restoring. The budgetary framework has been strengthened by the introduction of expenditure ceilings in 2013 which have the advantage of restraining expenditure increases in boom periods, but also allow the automatic stabilisers to work in downturns. Spending ceilings are, however, not binding each year but would only be activated in the case of a significant deviation from the medium-term objectives (MTO) or the correction path towards it. This design reduces the constraints imposed on expenditures in good times, when such ceiling is likely to make the most for fiscal consolidation. The commitment to medium-term objectives could also be strengthened by making budget targets binding on a multi-year basis while they are currently binding only for the first year of the budget, the two following years being only indicative. Medium-term expenditure ceilings, anchored by realistic budget fundamentals, would allow for the identification of the priorities behind the needed consolidation measures and help create the confidence that such measures would be lasting.

\section{Longer-term sustainability issues have to be dealt with}

Efficient forward planning of ageing related programmes, such as pensions and health, which make up around half the budget, is essential for budget consistency and credibility. Demographic spending pressures are due to rise considerably, as Slovakia will have the steepest increase in the old-age dependency ratio of all EU member states up to 2050: spending will rise by 3.5\% of GDP, of which $1.5 \%$ of GDP to meet public pension commitments and $2 \%$ to health care - the second highest projected increase 
in health care expenditure of all the EU member states (EC, 2012a, 2013a). The total consolidation effort required to maintain the budget at close to structural balance is thus of the order of $7 \%$ of GDP.

As a step towards longer-term sustainability, major changes to the public pension system were adopted in 2012 and to the armed forces pension system in 2013, which should reduce the projected increase in pension expenditures in the 2010-60 period, (SP, 2014). However, short-term economies have been made partly at the expense of reducing the future contribution from the funded pillar, which could add to the longer-term sustainability problem, and with the exception of low earners the changes in the calculation and indexation of pensions are likely to reduce the replacement rate in the long run. Even though new pensioners with low pensions (who earn up to 1.25 of the average wage) will not be affected by this decline, this may raise political pressures to increase the pension funding from general budget sources. Given that the scope for increasing social contributions is very limited (see below), ensuring sustainability rests on increasing the efficiency of the old-age income replacement system. One way to do so is to further adjust the pension age, which will require major improvement in the employability of older workers. Furthermore, increasing the employment rate and productivity would create room for financing public pension obligations. In that context, and taking account of possible future pressures to raise the replacement ratio, the reforms have not yet fully addressed all problems of sustainability within the public pensions system.

Compensating for the implicit liabilities built into the health system requires action. Slovakia commits fewer resources to health than the EU average (6.2\% of GDP versus 7.1\% of GDP in 2010, respectively) and public expenditure on hospitals, both as a share of GDP and as a share of the overall public healthcare budget, is one of the lowest in the EU. But healthcare expenditure has been growing rapidly as a proportion of total government spending and hospital debt has been rising, with overdue liabilities almost doubling from 2011 to 2012 (NRP, 2014). Moreover, rapidly increasing spending does not necessarily lead to better health outcomes, which in Slovakia are rather below-average for the amount of resources committed (Figure 1). Inefficiencies are, for instance, evident in a high number of facilities and acute care beds and a high average length of inpatient stays (OECD, 2012a, EC, 2014a). Inefficiencies are compounded by inadequate accounting and an absence of effective monitoring of hospital activity. Without increased planning and institutional and management efficiencies, the health sector will continue to be a source of budgetary disruption. Demographic pressures on the health service will not subside, but Slovakia could achieve better results if it reached the frontier of best performance.

Figure 1. Resource inputs and outcomes in the health sector

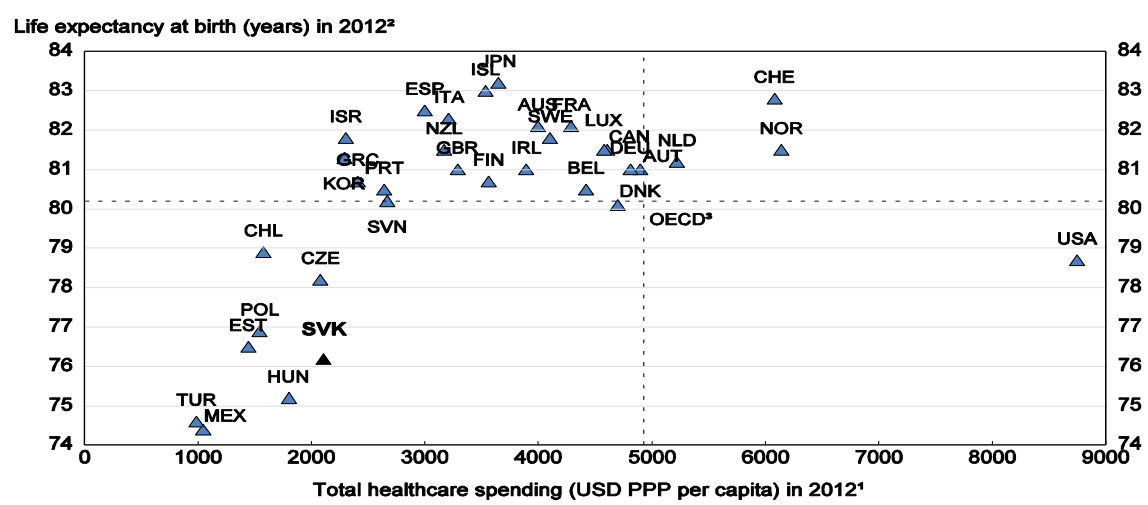

1. 2011 for Australia, Netherlands, New Zealand, Portugal and Spain. 2011 for Canada and United States.

2. 28 countries for which both of health spending and population are available. The following countries are excluded: Australia, Mexico, Netherlands, New Zealand, Portugal and Spain.

Source: OECD Health Database and OECD National Accounts Database. 
The NRP proposes a comprehensive effort to make the health budget more sustainable (NRP, 2014). It envisages the introduction of an integrated model of health care provision where the position of general practitioners will be reinforced to reduce unnecessary and expensive treatment in hospitals, and by enhanced information systems, improved hospital management, centralised procurement and the introduction of diagnosis-related groups (DRGs); hitherto, remuneration of hospitals has been on a per diem basis, encouraging a high number of in-patient cases. The government has also enhanced transparency on the healthcare market and information awareness of patients by obliging health insurance companies to publish all contracts with healthcare providers. There are also plans to unify health insurers into one public provider, to alleviate comparatively high administrative costs. In December 2013, the government adopted a 2014-30 Strategic Framework for Health to improve cost-effectiveness, which is an important complement to better control mechanisms in hospitals and now requires detailed implementation. The extent to which the health budget will be easier to control and predict is unclear and the situation will require constant monitoring, but better-designed incentive structures allied to costcontainment should help significantly in that regard.

\section{Allocative efficiency: spending should address priorities more effectively}

\section{Spending patterns do not reflect the priorities of a catching-up economy}

Slovakia has a relatively small general government sector (Figure 2) and hence relatively small public spending per head. As income per capita converges and the population ages, it would be expected that the resource demands made by some income-elastic and demographically driven programmes would tend to expand. The emphasis thus needs to be on controlling and reducing wasteful public expenditures.

Figure 2. General government spending

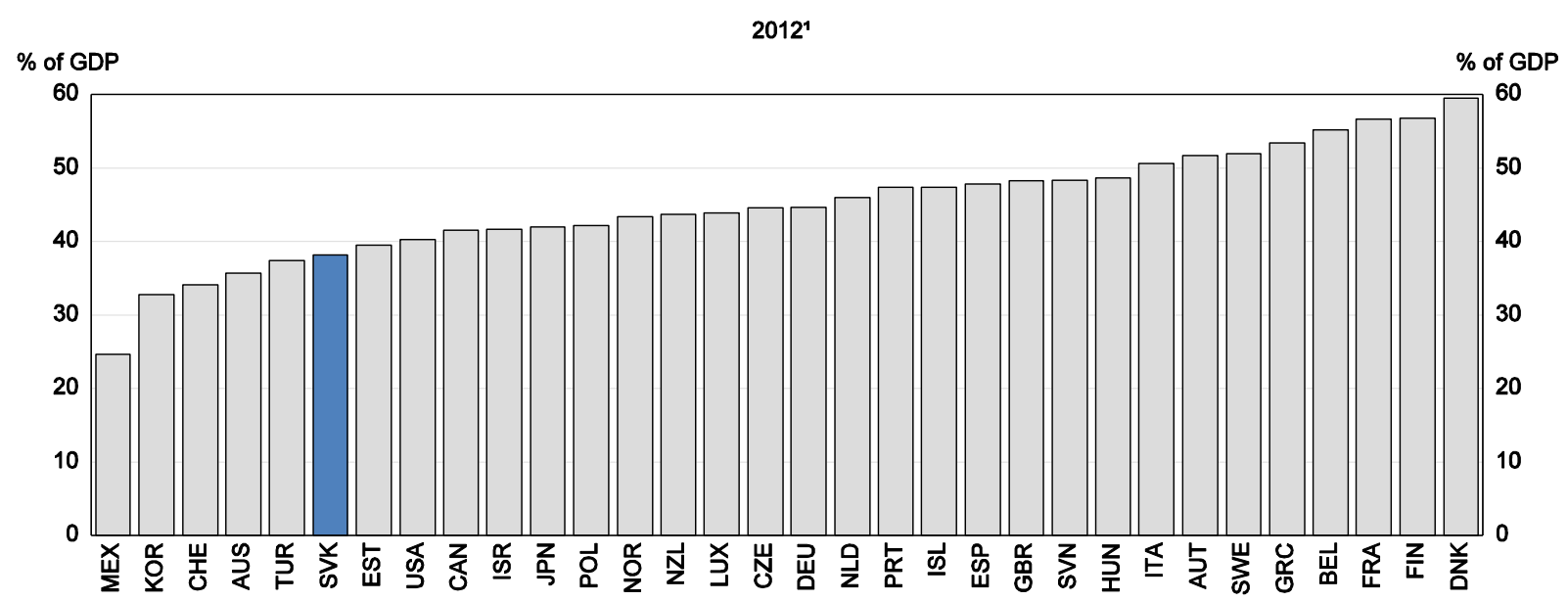

1. 2011 for Turkey.

Source: OECD Economic Outlook 95 Database.

The composition of spending is markedly different from what is typical in the OECD (Figure 3). As noted in the 2012 Economic Survey, social transfers in general are smaller but more effectively targeted than the OECD average (OECD, 2012a). However, general services and public order account for a relatively high $22 \%$ of government spending, while education and economic affairs (including transport and communication, industry, R\&D) spending is low (Figure 3). These are areas where spending needs to be expanded. This is reflected in the prioritisation in the current Budget towards areas of spending promoting economic growth; state expenditure on education, R\&D and the development of transport infrastructure are all scheduled to rise relatively fast (SP, 2014). The necessary prioritisation of spending 
towards these growth-enhancing areas was discussed in the 2012 Survey; this section elaborates on the instruments available for effecting such prioritisation.

\section{Figure 3. Composition of general government spending}

\section{A. Slovak Republic}

2012

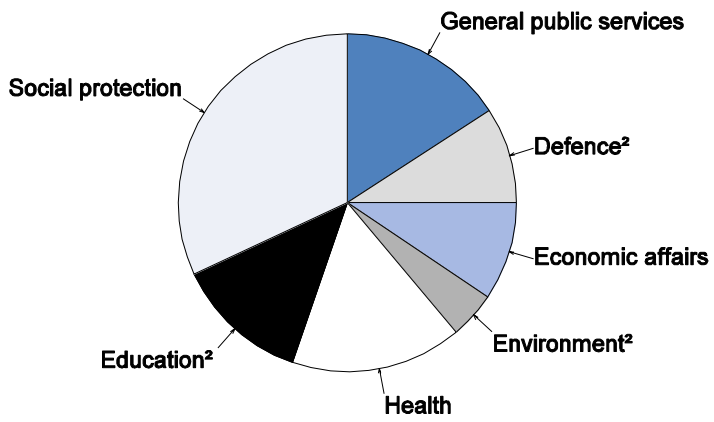

B. Smart economies ${ }^{1}$ 2012

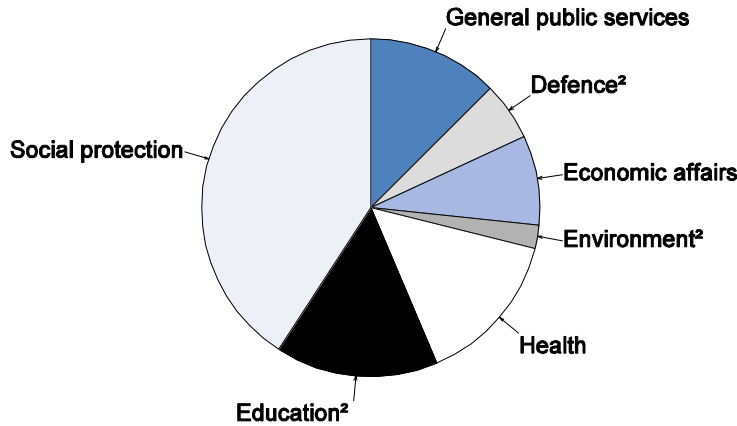

1. Smart economies comprise the top five European economies according to OECD Better Life: Netherlands, Denmark, Sweden, Norway and Switzerland.

2. Sectors based on the Classification of the functions of government 93 (COFOG) at 2-digit level of which three sectors are aggregated: Defence including public order and safety; Education including recreation, culture and religion; and Environment including Housing and community amenities.

Source: OECD General Government Accounts Database.

\section{More resources and better performance in education}

Higher spending on education offers the prospect of high rates of return and reductions in income inequalities. The net present value for an individual with upper secondary education is high compared with the OECD average (OECD, 2013a). Conversely, levels of long-term and youth unemployment are worryingly high and pose a significant potential problem for future growth if this segment cannot acquire employable skills. Around $60 \%$ of the unemployed have a low level of education and the increased risk of unemployment for Slovaks without upper secondary education is particularly strong. This disadvantage appears to be self-perpetuating, since children in homes with an unemployed parent are at far greater educational risk than on average in the OECD (OECD, 2013a). Educational disadvantage is also linked to regional disparities. While there is a greater degree of income equality in the Slovak Republic compared to the majority of OECD countries, there is a particularly high concentration of poor households in the eastern regions, which means that regional disparities are much more pronounced than in other OECD countries (see Chapter 2).

Slovak educational performance is below average, in the secondary sector at least, as evidenced by PISA results, and international comparison suggests some room for efficiency gains (Figure 4). High youth unemployment partly reflects the low quality of the education and training systems and their limited relevance to labour market needs (Chapter 2). But relatively low public expenditure in education and the poor attractiveness of the teaching profession probably also explain this problem (OECD, 2012a).

Recently adopted and proposed reforms attempt to correct these deficiencies. Notably, the NRP sets the objective of gradually increasing public expenditure on education to $6 \%$ of GDP - the average of EU countries - by 2020. At the same time, the wages of pedagogic and professional staff in education are being increased, making teaching financially more attractive, following recommendations in the 2012 Economic 
Survey of the Slovak Republic (OECD, 2012a). The remuneration of teaching staff is generally positively linked with teaching outcomes (Sutherland et al., 2007). Efforts to improve the attractiveness of educational careers should be continued, given the gap between teachers' salaries and the average wage of tertiary-educated individuals in Slovakia: $44 \%$ in 2010, as against $82 \%-90 \%$ on average in OECD countries (OECD, 2013a). To improve the attractiveness of teaching careers and the quality of education, the NRP is to improve the initial training of teachers and implement continuous monitoring of the recently introduced career system for teachers.

The higher education reform adopted in December 2012 also aims to improve internal quality assurance systems and the quality of part-time studies and teaching, while increasing the incentives to increase the internationalisation and business relevance of higher education institutions. A comprehensive new law on higher education institutions is under consideration, as is a revised funding mechanism that would link the financing of education more closely to the overall quality of education.

Figure 4. Education outcomes in secondary education and spending per student

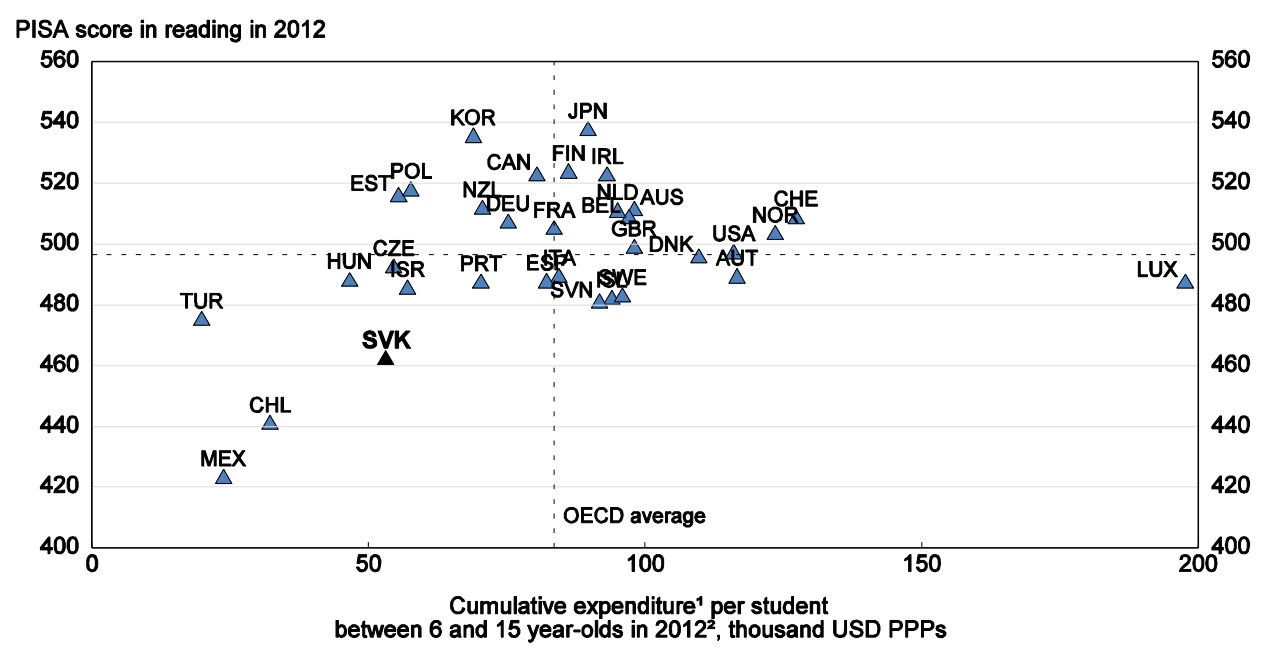

1. Public institutions only for Hungary, Ireland, Italy, Poland, Portugal, Slovenia and Switzerland.

2. 2009 for Chile and Germany. 2011 for Canada.

Source: OECD (2013), Education at a Glance and OECD PISA Database.

\section{Infrastructure investment is below normal}

Public investment has declined over the past few years to relatively low levels compared to other catching-up economies (Figure 5, Panel A). Certain elements of infrastructure - electricity and telephony infrastructure for example- compare well; other important areas, particularly transport, do not according to World Economic Forum (WEF) indicators. Employers identify transport as one of the main barriers for doing business (Figure 5, Panel B). Developing infrastructure in Slovakia could be highly beneficial to growth (Sutherland et al., 2009), business ratings of the distance from the best-practice frontier being substantial for transport infrastructure in particular (Figure 5, Panel C).

The focus is currently on modernising the road transport system, particularly motorways and expressways, one aim being to link regions with a lower economic performance and a high unemployment rate into the system (Chapter 2). For any infrastructure investment drive to be effective, clear rules are needed for setting priorities. The Slovak government is considering introducing an Act on Traffic Authority to ensure smooth, functional and economical strategic planning of transport, but so far no budget for such measure has been prepared. The financing mechanism could be based on fees received from 
market participants. Public-private partnerships (PPPs) also offer the possibility of reducing the budgetary burden of infrastructure projects. Towards this objective, PPP projects are for instance under preparation for the construction of the expressway R1, a section of highway D4 and the first three sections of the expressway R7. Such schemes should be closely monitored such that they do not create hidden contingent liabilities and risk is fairly distributed between public and private sectors (OECD, 2012b). That has not always been the case, two out of three PPP highway projects having been cancelled in Slovakia in 2010 due to non-transparent procedures and high cost of financing compared to a financing based only on EU and public funds (OECD, 2012a).

Figure 5. Government investment and infrastructures are low

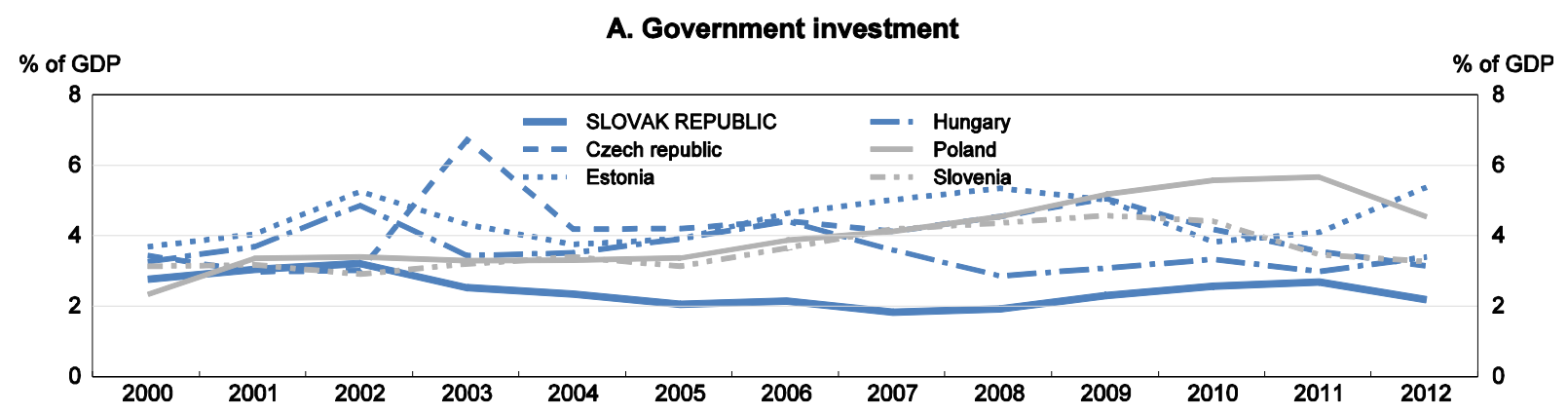

B. Most problematic factors for doing business'

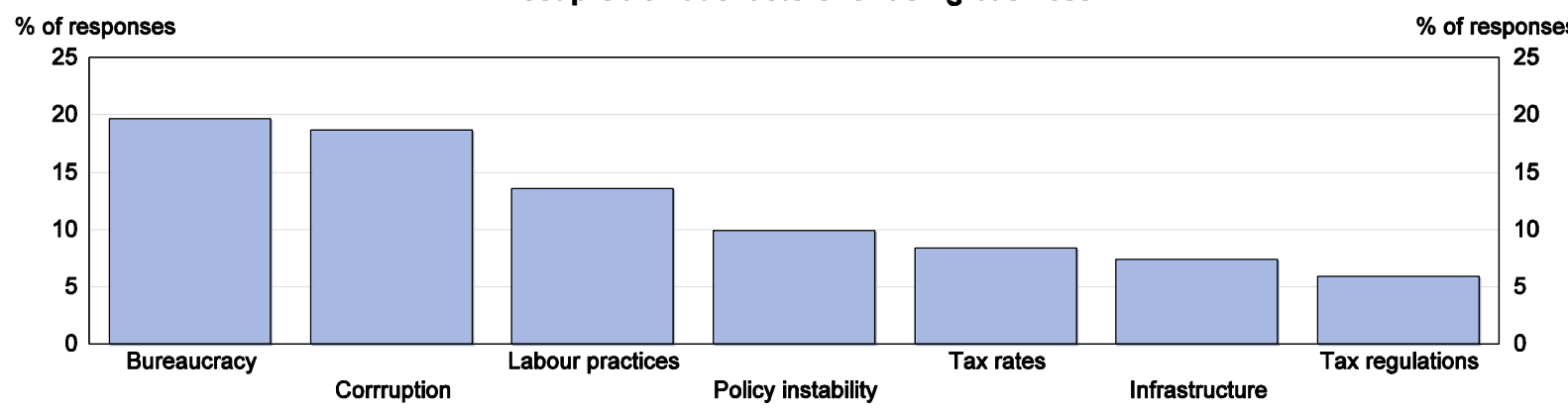

C. Business ratings of the quality of infrastructure

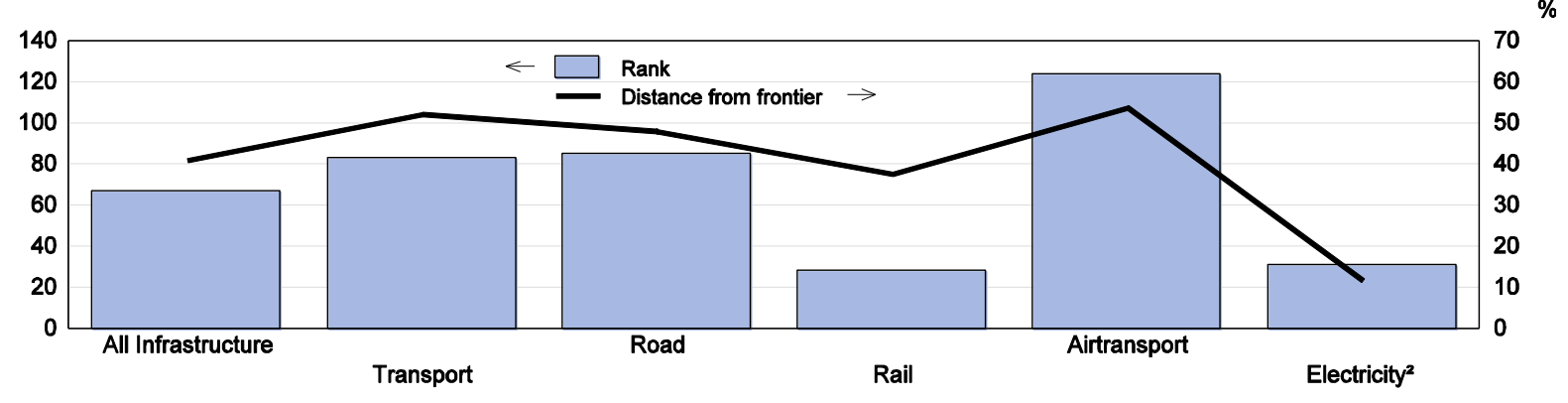

1. Inefficient government bureaucracy, Corruption, Restrictive labour practices, Policy instability, Tax rates, Inadequate infrastructure and Tax regulations.

2. Quality of electricity supply.

Source: OECD Economic Outlook 95 Database and World Economic Forum (2013).

\section{Government investment in $R \& D$ could be selectively increased}

As is the case for education, public investment in research and development is low by OECD standards. Over time, investment in domestic company-level research has declined while technology 
imports have risen, via branches of multinational companies. Otherwise, the state of the knowledge economy remains rather backward, not just compared with the most advanced OECD countries (OPKE, 2011), while Slovak small and medium enterprises (SMEs) and the few large domestic-owned companies typically have low productivity levels and low R\&D intensity. Total Slovak Gross Expenditure on R\&D (GERD) and Business Expenditure on R\&D (BERD) as per cent of GDP are respectively about $40 \%$ and $25 \%$ of EU27 levels in 2012 (Erawatch, 2014).

The 2011 Innovation Policy acknowledged a 'disproportional reliance on the European and international financial assistance' and called for increased national funding for innovation (EC, 2014b). National innovation funding accounts for a limited part of overall funding and lacks a clear thematic focus. In response, the 2013 National Reform Programme sets 2020 targets for gross domestic expenditure on R\&D and business expenditure on research and development at $1.2 \%$ and $0.8 \%$ respectively. The intention is to concentrate state support for R\&D on selected priority areas where Slovakia has comparative advantage, such as material research and/or information and communication technologies. The goals for innovation development are elaborated further in the national Smart Specialisation Strategy, which identifies key areas of economic specialisation and presents far-reaching plans for institutional reforms in the public sector (higher education institutions, Slovak Academy of Sciences, research funders). To increase the share of private resources in $\mathrm{R} \& \mathrm{D}$, the government intends to promote development and innovation capacities in companies via the strengthening of various financing incentives, including R\&D tax credits and venture capital schemes (NRP, 2014). However, frequent changes in policy directions do not help and prioritisation is also important. It may be particularly important to encourage the transition of companies, especially subsidiaries of multinational corporations, from assembly and production to the development of their own products and technologies, which could be supported through clustering and other forms of networking at the local, regional, national and macro-regional level (OECD, 2014c).

\section{Institutional efficiency: reducing budget fragmentation and improving co-ordination}

\section{Towards a more holistic approach to policy making}

Achieving a more efficient resource allocation in public spending will necessitate more effective coordination. The focus of the ongoing administrative reform process launched in 2012 is thus to create a more holistic approach to policy-making, first by creating greater cohesion among administrative institutions and second by ensuring more effective collaboration between the state and sub-national entities. Part of the problem has been that Slovak public administration tends to be relatively fragmented and organised around strong ministerial silos, with rigid departmentalism making it difficult to ensure that synergies across policy areas are fully exploited and duplication is avoided (OECD, 2014a). Many strategic priorities are cross-sectoral and the strict sectoral approach hinders their effective implementation. ${ }^{2}$

The success of reform effort depends on robust planning and co-ordination mechanisms, within a framework which allows strategic priorities to be set, via budget goals that are transparently defined and clearly aligned with budget instruments, while allowing systematic ex ante and ex post assessment and appraisal based on the promotion of evidence-based policy-making (like regulatory impact assessment and policy evaluation). Most notably, the following strategic weaknesses need to be addressed:

2. An example of this is climate adaptation with anti-flood measures which, in the case of ecosystem-based solutions, require the cooperation of the Ministry of Environment and its organisations that deal with water, biodiversity or climate, the Ministry of Interior Affairs that deals with the adaptation agenda, and the Ministry of Agriculture and Rural Development that has responsibility for agriculture, soil management and forestry. In this area, if co-ordination is lacking - and unfortunately it is - simple fast-track solutions with questionable adaptation effects, such as dam building, will be preferred. 
- Collaboration on cross-cutting projects is inadequate. There is a wide network of advisory boards, usually attached to specific ministries; the line ministries lead on their policy areas and the Council of Ministers takes final decisions on key issues. This leaves a gap, where complex policies and reforms that cut across traditional ministerial lines of command need to be addressed more collectively before they can be put to the Council of Ministers (OECD, 2014a).

- Strategic planning is difficult. There is a range of processes for different purposes, including short and much longer term strategic plans, additional to the Programme Declaration of the government. As line ministries are often in charge of these, timelines and methodologies can vary, which makes it particularly hard to align strategy with budget. Moreover, processes and institutions for ensuring the quality of impact assessment throughout the decision-making process are not yet well developed (OECD, 2014a).

- Analytical capacity is limited. Experience shows that the ministries responsible for the implementation of structural policies may not always have sufficient in-house expertise in relevant areas (Slovak government, 2013). Conceptual thinking is often absent and the quality of proposed solutions is compromised.

- Monitoring and evaluation processes are undeveloped. There are relatively large differences in the use of performance measurement across sectors. There is a tendency to focus on inputs and tasks rather than outputs and outcomes (OECD, 2014a).

- Problems of central-local co-ordination. A further set of problems arise from difficulties of central-local co-ordination, seen in the reluctance of national ministries to delegate control over the EU funds to lower governance levels. Slovak ministries are, for example, sceptical of the ability of municipalities and regional authorities to implement EU funds efficiently and on time (Bucek, 2011).

Correcting these weaknesses would make forward budget planning and prioritisation easier, achieving greater consistency and continuity. To some extent, better co-ordination needs to come from the centre. For instance, the creation of the position of the Deputy Prime Minister for Investments, whose portfolio also includes coordination of preparation and implementation of the Partnership Agreement of the Slovak Republic for 2014-20, should improve co-ordination and prioritisation of public infrastructure investment. Institutions and incentives that support this position could help ensure that co-ordination and prioritisation is sustained over time (OECD, 2014a). There is also an ongoing effort to set a planning horizon that goes beyond the electoral term of the government in office and this needs to become established practice, in conjunction with the expenditure ceiling approach discussed above. To improve analytical capacity, analytical units are being set up by key social and economic ministries ${ }^{3}$ and their effectiveness will depend on attracting sufficient expertise into the civil service: policy and strategy development, impact assessment, budget programming, monitoring and evaluation all require the building of a skilled and professional corps of civil servants. This needs to be fostered via civil service reforms (discussed below) which would help set a dividing line between political and non-political functions.

\section{Getting the most out of EU structural funds is a key co-ordination challenge}

Co-ordination problems have been most serious with respect to absorbing EU structural funds. At the end of 2012, Slovakia's contracting rate at $73 \%$ was the second lowest among CEE countries. It then increased abruptly in an attempt to fully absorb EU funding prior to the deadlines of 2007-13 programming period, though such a massive surge might have resulted in deteriorating project quality and so should best

3. For example, the job of the newly created Educational Policy Institute EPI is to prepare analysis, to forecast, and to give expert advice concerning strategic policy decisions in education, in co-operation with relevant ministry’s departments (Šiškovič, 2013). 
be avoided. This acceleration comes also with higher risks of irregularities and hence suspension of payment by the EU. In addition, it imposes tight deadlines to declare costs, as all the expenditures on projects that have to be reimbursed by the EC must take place by the end of 2015. Overall, several programmes had to speed up the absorption by more than $50 \%$ in 2013 .

The incapacity of local administration to absorb the funds efficiently is linked to an extremely burdensome national system of structural funds administration, based on complicated rules and requirements; at the same time there is some evidence that the quality and the transparency of the selection process of certain projects have been low:

- The complexity of EU structural funds administration often goes beyond what is required by European institutions. Two important lost opportunities have been the slow adoption of simplified cost options, which would enable beneficiaries to claim indirect costs through a fixed formula, and of a simplified application process, which would postpone the need to gather all official verification after the application is accepted (CKO, 2011; EC, 2011).

- Administrative capacity has been inadequate, with an insufficient use of e-government, and human resource problems, including high staff turnover linked to political cycles. Almost $18 \%$ of administrative staff in charge of EU funds management left between June 2012 and June 2013 (CKO, 2013). However, on a more positive note, a unified organisational structure with training for the administration of EU funds has been introduced.

- There has been a marked lack of transparency in the project selection process and in public procurement. This is a key barrier to the efficiency of the EU structural funds absorption and poses a significant threat to the quality of projects and their cost efficiency (CKO, 2011; EC, 2012b). The situation contributes and aggravates the corruption problem in Slovakia, which is discussed below.

- There is a lack of instruments to measure and evaluate work performance. Over the years 2009-11, less than one half of planned evaluations of operational programs were implemented. With respect to the evaluation of individual projects, enlarging the toolkit remains a challenge; for example, projects could be evaluated based on the deviation from proposed measurable objectives.

On a positive note, some steps have been already taken to improve the administration of EU funds, such as the semi-annual publication on the implementation of EU funds that allows the authorities to react promptly in case of identified problems regarding absorption of the funds. Administrative procedures have also been simplified and allow the managing authority to request only partial project documentation upon the application submission, the rest of the documentation being required only after projects are selected. Some measures have also been taken at the European level to reduce the administrative burden for the next programming period, including the extension of simplified cost options to other types of costs. This extension will be challenging for Slovakia which has almost no experience with these options, compared with other countries. As part of the simplification measures, requirements for audits will be reduced. But to ensure that this will not be associated with greater corruption, simplification needs to be supported by transparent project selection and public procurement.

Better absorption is critical because the European Union structural funds offer Slovakia an opportunity to tackle its regional disparity problem while strengthening the development of the country as whole. Slovakia has been among the countries with the highest funding per capita and this high level of funding will continue in the forthcoming 2014-20 programming period. The current year is pivotal as the work on the 2014-20 programming period needs to be finalised: operational programmes have to be submitted to the European Commission by the end of September and signed by the end of December 2015. Insofar as governance has been an issue in the amount and distribution of funds, there is a need to address early the administrative impediments to the take-up and efficient implementation of EU structural funds (EC, 2013). In particular, guidance for the preparation and the selection of projects should be improved to 
raise the quality of projects applications, the transparency of the selection process should be increased and the assessment time of the certification authority should be reduced. Capacity for more evidence-based decision making should be built. With past deficiencies in mind, a key ex ante condition attaching to the EU Cohesion Policy and the release of funds has been that the Slovak Republic adopt a strategy for reinforcing administrative efficiency including public administration reform and modernisation (OECD, 2014a). To tackle those challenges, the authorities have hence launched a separate operational programme to support the building of an effective public administration (OP EPA).

\section{Improving central - local co-ordination}

While Slovakia is highly centralised in terms of revenues and spending autonomy (OECD, 2014c), it is also characterised by a large transfer of responsibilities to local units of the central government (Box 1). One crucial defect of this system has been the disintegration into specialised structures which are territorially and organisationally miscellaneous and difficult to manage. To correct these defects, the administrative reform programme has taken steps to make central direction more effective, the first stage having being completed in October 2012, when parliament approved a law replacing the system of socalled "specialised" state administration with a more centralised, integrated system. With this, the regional specialised public administration offices have been integrated into district authorities. The aim is to improve both the administrative and allocational efficiency of the Slovak public administration system. Rationalisation has indeed begun to have benefits: the merger of local government offices has also brought savings: for example, expenditures on operation and administration of buildings and costs of public procurement have already dropped, while further efficiency savings are expected from the non-replacement of posts in closed regional state offices.

\section{Box 1. Decentralisation in Slovakia}

There is a dual system of 1) decentralisation that is meant to ensure the autonomous functioning of regional and/or local state administration, and 2) 'deconcentrated' state administration that refers to the transfer of responsibilities to local units of the central government.

1) The framework of self-government is organised into two main levels without hierarchical ties between them but which function on the basis of mutual co-operation:

- The local level represented by 2926 municipalities.

- The regional level represented by eight self-governing regions. The Constitution refers to the eight autonomous regions (samosprávne kraje) as "higher territorial units" (Article 64) and since 2002, they have been responsible for specific competences in several areas, and also for carrying out competences delegated by the central level of government.

2) The framework of "deconcentration" of state administration is subdivided into two aspects:

- The general state administration; it is decentralised from the central level (Government Office, Ministry of the Interior) to the district level (district offices of general administration). This scheme applies, for instance, to administration procedures linked to entrepreneurship, general interior affairs, civil security or citizenship.

- The specialised state administration; it is decentralised from the central level (government, ministries except for the Ministry of the Interior) through the regional level (regional offices of specialised state administration) to the district level (district offices of specialised state administration)..

The risk from the current streamlining of local services is that 'top-down' decision-making will become more dominant and the potential for local initiatives and regional development led directly by local stakeholders will be limited in the interests of ensuring a more efficient administration - of cohesion funds for example. To preserve the benefits of local democracy, while reaping efficiency gains, the reform could go further, embracing not just the rationalisation of the regional/district organisations but also bolstering the autonomy of the excessive number of municipalities, via a process of merger and consolidation or 
inter-communality $(\mathrm{OECD}, 2014 \mathrm{c})$. Merging municipalities and reducing the number of administrative intermediaries could generate significant efficiency gains, while also helping to prevent a recurrence of the central/local co-ordination problems thrown up by the crisis, which saw local governments running into debt. Such a merging process has been implemented for instance in Canada, Denmark, Japan and Turkey. An alternative to merging retaining some of the efficiency gains would be to provide incentives for cooperation. The need to reduce administrative fragmentation is generally acknowledged: municipalities can already cooperate or even establish joint communal offices: there are 233 such offices in Slovakia covering almost all of the 2926 municipalities, which could form a basis for joint provision of services across small municipalities. In a first step the current system of joint communal offices would have to be streamlined and joint provision of services across municipalities organised in order to exploit efficiency gains.

\section{Management efficiency: modernising the public administration}

Modernising the public administration is the key enabling policy for improving performance of the public sector. It is an essential plank of the public administration reform as set out in the Strategic Framework of Public Administration Reform and the National Reform Programme, which was motivated by the perception that the Slovak public administration continues to underperform in terms of both quality and efficiency. For example, bureaucratic inefficiencies are cited as the most important impediment to business expansion (see below). Problems appear to be systemic, focused on the following areas:

- Performance measurement is undeveloped. Currently, there are relatively large differences in the use of performance measurement across sectors and there is a tendency to focus on inputs and tasks rather than outputs and outcomes.

- E-government is underused. One of the means to achieve greater efficiency is through a wider use of electronic means and reinforced analytical capacities in the state administration; IT systems are an essential interface between citizens and governments.

- Human resource management needs to be improved. Problems associated with a high turnover of civil servants are aggravated by a low use of strategic human resource practices such as planning, performance assessment and predictable career paths.

- The integrity of the civil service is compromised by corruption. Corruption raises costs and reduces the quality of public services, while undermining the trust in the government.

\section{Results-oriented budgeting would improve administrative efficiency}

Within the scope of binding expenditure ceilings, where high-level budgetary allocations are made centrally, budgets need to be implemented flexibly to ensure efficiency and service quality, based on results. Typical elements in a programme to devolve decision-making include increasing end-of-year flexibility (carry forwards). This requires a degree of 'top-down' budgeting, which would involve each ministry being allocated funds (typically ring-fenced into economic categories), but being given more freedom in allocating them among agencies and programmes. In this respect, Slovakia already implements top-down budgeting and responsibilities delegated to line ministries broadly accord with international standards. While, as in most other OECD member countries, line ministries cannot decide on the allocation of the budget envelope between payroll and other expenses, or on the number and types of posts in organisations, capital expenditures are allowed to be carried forward and carry-forward for current expenditure is allowed within limits. However, consideration should be given to expanding these responsibilities further to increase managerial flexibility.

A focus on performance and results is the necessary accompaniment to greater managerial flexibility and a robust system of internal and external controls needs to be in place to prevent abuse. Administrative 
capacities and related follow-up assessments are currently too weak to ensure that public spending programmes are implemented efficiently (Figure 6). To help correct this, the government has started to develop evaluation practices in each line Ministry and the Council for Budgetary Responsibility (CBR) is in charge of assessing the fiscal impact of policy proposals in parliament. The public sector has inadequate capacities and infrastructure for the creation and evaluation of policies, and there is little emphasis on customer satisfaction and the factors determining it - waiting time and length of the administrative process, for example. The role of the civil society organisations in public policy making and monitoring of policy implementation is also currently undeveloped.

To make monitoring effective, appropriate performance and results information should be included in the annual budget documentation. Such indicators should offer an understanding of how the goals of various governmental policies and spending programmes are being achieved and could be used to assess spending effectiveness. Performance reporting should be carried out in a transparent manner and in a userfriendly format to avoid a useless swelling-up of budget documentation. The Slovak authorities could draw on OECD countries' experience in conducting their own performance evaluations. For example, Australia's Productivity Commission publishes an annual review of government programmes that is used in the budgetary formation process.

Figure 6. Resource inputs and performance in government general services

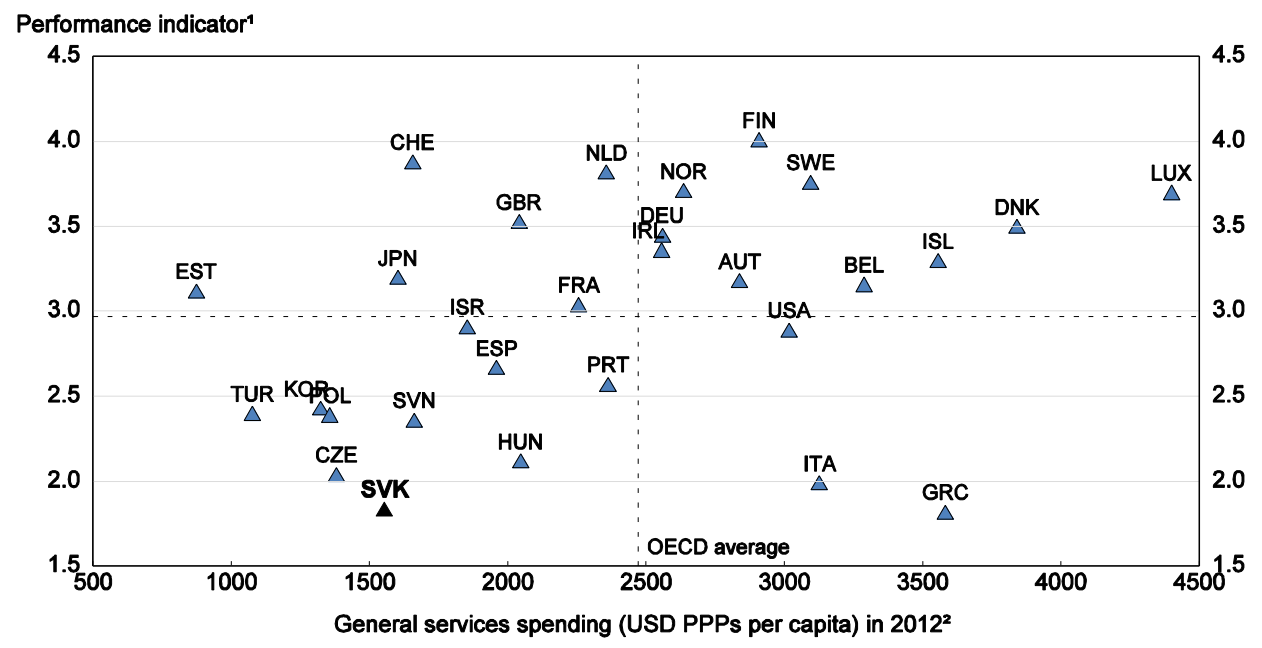

1. Composite performance indicator for public administration outcome based on OECD's Product Market Regulation Indicator (for 2008) to proxy the levels of bureaucracy and results of the 2012 WEF survey on the quality of justice, level of corruption and government inefficiency (data for 2010).

2. 2011 for Austria, Korea, Luxembourg and Turkey. Data unavailable for Australia, Canada, Chile, Mexico and New Zealand. OECD aggregate across countries for which data in 2012 are available.

Source: Calculations based on OECD Product Market Regulation Statistics and WEF (2012), The Global Competitiveness Index 2012-2013 Data Platform; World Economic Forum; and OECD National Accounts Database.

With its Public Finance Management reform, important progress has been made notably in respect of standardising accounting procedures, shifting from the cash principle to accruals and improving the content of budget documents. The Supreme Audit Office provides value-for-money audits, though the outcomes of these audits are not yet used in budgeting procedures. The ex post audit processes should be improved by allocating more resources to the monitoring of programmes and evaluation outcomes should be taken into account in budget allocation. Budgeting procedures could make better use of international benchmarking by identifying best practices in this regard. Also, publishing a citizen's guide to the budget is good practice in international fiscal transparency initiatives by increasing accountability for individual 
spending areas (IMF, 2007). The current project of the authorities to create a website with user friendly information on the budget goes in the right direction.

Achieving greater transparency in public procurement is an essential element in cost reduction, especially given that the Slovak Republic spends around 11\% of GDP on procurement, more than the EU average (Figure 7). Important progress has been made in this direction. Since the second half of 2010, the government has operated a mandatory electronic central registry of contracts on its central procurement website for the whole public administration, in which the dissemination of tenders, tender documents, the submission of bids and the publication of notification of awards is done publicly through a single portal. Contracts signed by general government organisations and municipalities, as well as any contracts involving public funds, become effective only after their publication. The single-entry procurement website is one of the few in the OECD that allows users to track the outcomes of contracts, an important functionality for making the public procurement transactions more transparent, increasing the scope of oversight by the civil sector. Nevertheless, there are still gains to be made by lowering barriers further, by ensuring that data is made available in more suitable and machine-readable formats (Fernas, 2013).

Figure 7. Public procurement

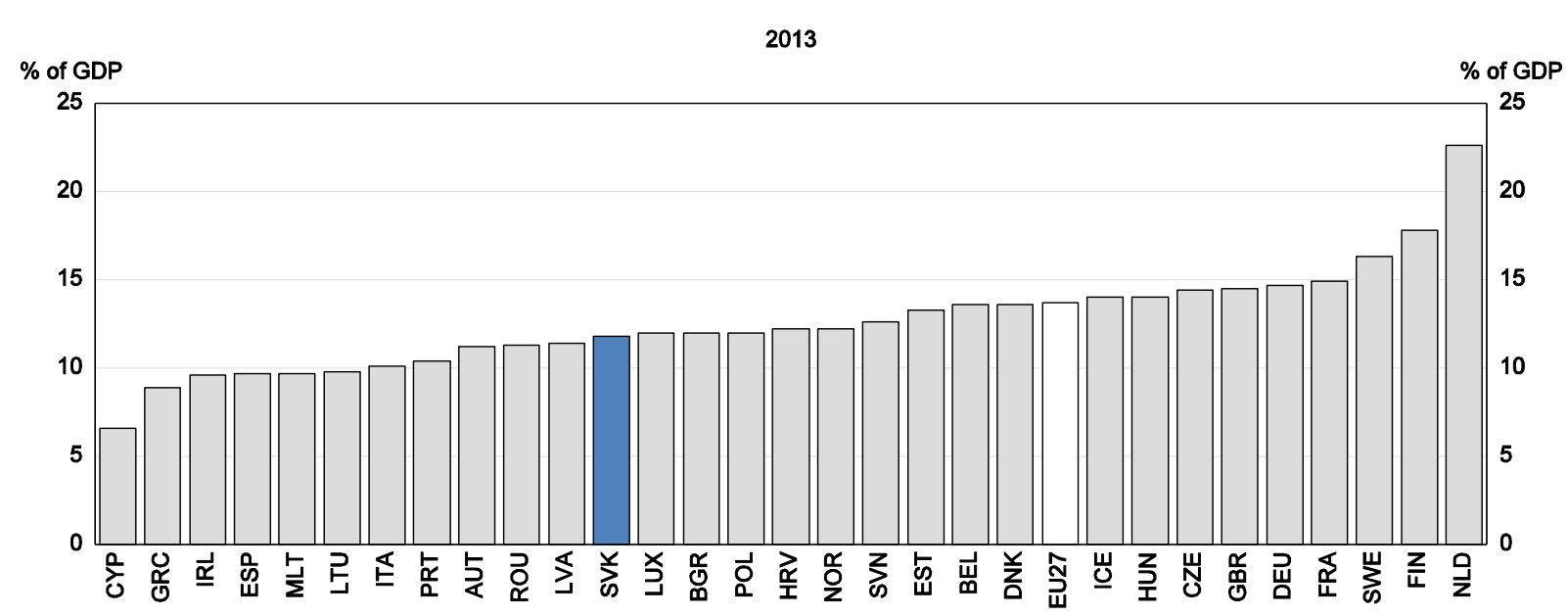

Source: Eurostat.

Manipulation of public procurement occurs either before or after the awarding of the bid, rather than during the decision process itself, which is now heavily regulated. Prior to the submission of bids, procuring authorities can limit competition and manipulate the results of the tender process by custom tailoring a contract or setting unreasonable conditions on who can submit a bid in the first place (Fernas, 2013). In that respect, public procurement still lacks some important elements of transparency insofar as Slovakia does not publish justifications for awarding a contract, which $40 \%$ of OECD member countries already do (OECD, 2012c). ${ }^{4}$ Furthermore, formal mechanisms and institutional means of sanction are also not currently very effective (Fernas, op. cit.). Efficiency is also impaired because procurement rules restrict the choice of evaluation criteria, so that state institutions are discouraged from making decisions on the basis of procurement quality. The 2013 Public Procurement Act reform, goes in the right direction, notably by allowing that not only cost but also quality considerations are taken into account. However, complaints have not reduced since the reform, pointing to the need for closely monitoring the implementation of this reform (Chapter 2). Also, the procurement authorities should ensure that the Competitive Dialogue

4. As of 2012, information on the justification for awarding contracts was available in thirteen OECD member countries and contract modifications were publicised in eleven members; however, only six countries provided information that allowed the tracking of procurement spending (OECD 2012c). 
procedure - a more flexible procedure defined by the EU Commission and consisting of a pre-selection of candidates followed by a dialogue with bidders with the aim of developing suitable solutions to meet procurement requirements - is used for complex projects. In some areas current procurement rules are also perceived to be too difficult to apply. A task force should be implemented to provide recommendations as to how procurement rules could be made easier to apply without undermining their original intentions of fighting corruption and increasing efficiency. Slovakia is similarly lagging behind in term of e-procurement (Figure 8, Panel A), which not only reduces transaction costs and improves timeliness, but also enhances transparency and hence reduces the risk of corruption. For example, over half of OECD countries provide contract management tools via their portals, such as tracking contract outcomes or statistics related to past procurements.

\section{E-government is underused}

Slovakia has a relatively low level of online interaction between the public and government (see Figure 8, Panel A). For example, while citizens widely use government websites to find information, they very seldom use it to send forms. This increases the pressure on administrative resources, for example in the tax, administration and judiciary systems. A survey by the United Nations shows that in 2012 Slovakia ranked fourth worst among EU countries in the evaluation of e-government maturity, the areas furthest behind being online services and telecommunications infrastructure (UN, 2012). The Slovak Republic is also among countries with the lowest level of openness in terms of availability of public data, including reference data administered in public administration registers, which are needed for the exercise of public authority (State of Open Data, 2012). On the positive side, more recently, VAT payers, tax advisors and attorneys are required to communicate with the financial administration using online services.

Figure 8. E-government

A. E-government

Citizens' internet use to interact with public authorities in 2012

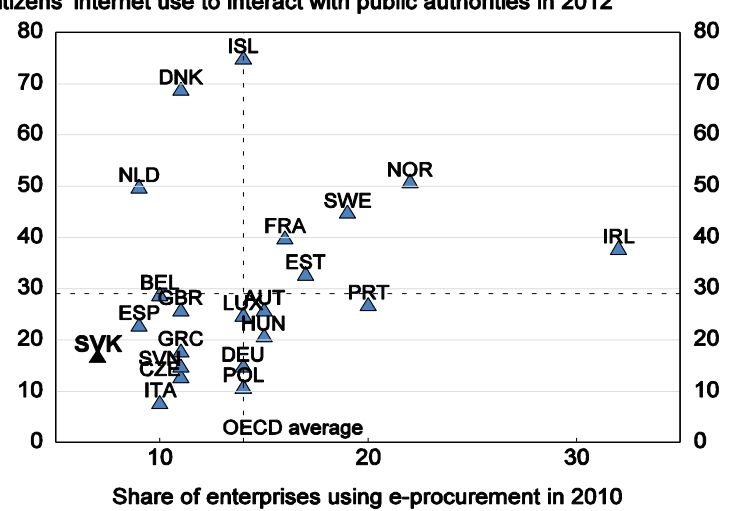

B. Performance and plans in e-government

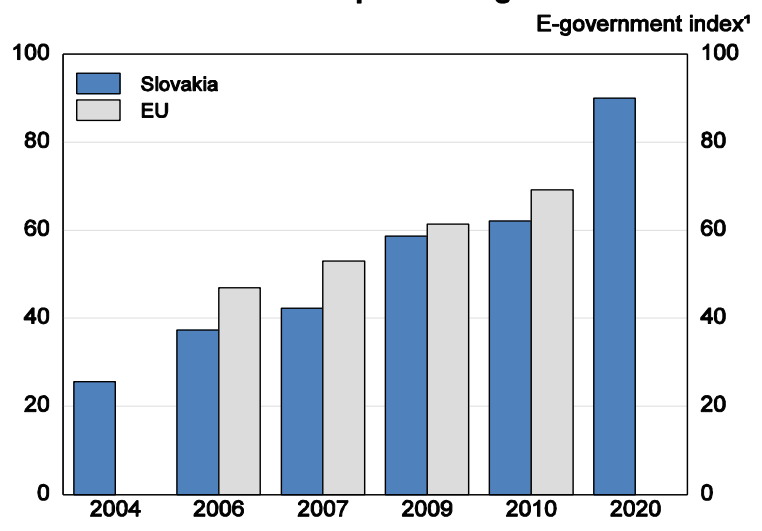

1. For any given country, the index is calculated as a weighted average of the following three indicators: e-Government availability ( $50 \%$ weight), individual e-Government usage (25\% weight) and business e-Government usage (25\% weight). The eGovernment availability measures the share of 20 basic e-Government services available via the Internet and the eGovernment usage measures the percentage of people/businesses who have, in the last three months, used the Internet in communication with public institutions.

Source: OECD (2011, 2013), Government at Glance and European Commission (2013), National Reform Programme of the Slovak Republic 2013.

The National Reform Programme (NRP) is quite ambitious in its plans for extending e-government (see Figure 8, Panel B), which will require a catch-up across a wide range of elements making up the 'digital agenda' (Figure 9). Full achievement will not be possible without further investment in skills, both within the public service and among the wider population. For instance, in Slovakia $24.2 \%$ of the adult population report no prior experience with computers or lack of very basic computer skills - one of the 
highest shares in the OECD (OECD, 2013b). Low broadband penetration, particularly in rural areas, is obviously also an important barrier. As for the measures implemented so far in the area of modernisation and electronisation of public administration systems, these are often solved separately by different organisations without any interconnectivity of systems, through which individual public administration bodies could exchange information. The adoption of measures to facilitate the effective development of an integrated public administration information system and to improve the interoperability of its services is thus essential, in addition to simplifying administrative procedures to facilitate the use of ICT tools and using ICT tools to meet the individual objectives of the administrative reform programme (Box 2).

\section{Box 2. Using e-government to make reforms effective}

The projects being implemented should facilitate the provision of e-government services at the transaction level:

- The new e-ID card is designed to enable on-line authentication and authorisation of citizens, while the central e-government portal will serve as a single point of access to all e-government services.

- $\quad$ The Strategy for the computerisation of public administration aims to provide the public with the necessary ICT and transaction e-services through suitable entry channels as well as by creating preconditions for their effective management and distribution, in line with the National Strategy for the growth of digital services.

In addition, ICT tools will help achieve the individual specific objectives of the administrative reform programme:

- $\quad$ Strengthening analytical capacities of the public administration - analytical computerisation systems will be put in place in the areas such as the simulation of policy impacts, risk analysis and the uncovering of fraud and the solving of specific needs of individual analytical institutions. A system of central e-learning will also be put in place, which will enable the implementation of employee education and training courses online.

- $\quad$ Support human resources management - through the means of a complex information system for the management of human resources in e-government cloud and related applications for quality management.

- $\quad$ Effective public procurement and transparency - open data in the area of public administration, central tools for public procurement and services in the e-government cloud will be implemented and central e-learning will be used in the educational processes. 
Figure 9. Digital agenda

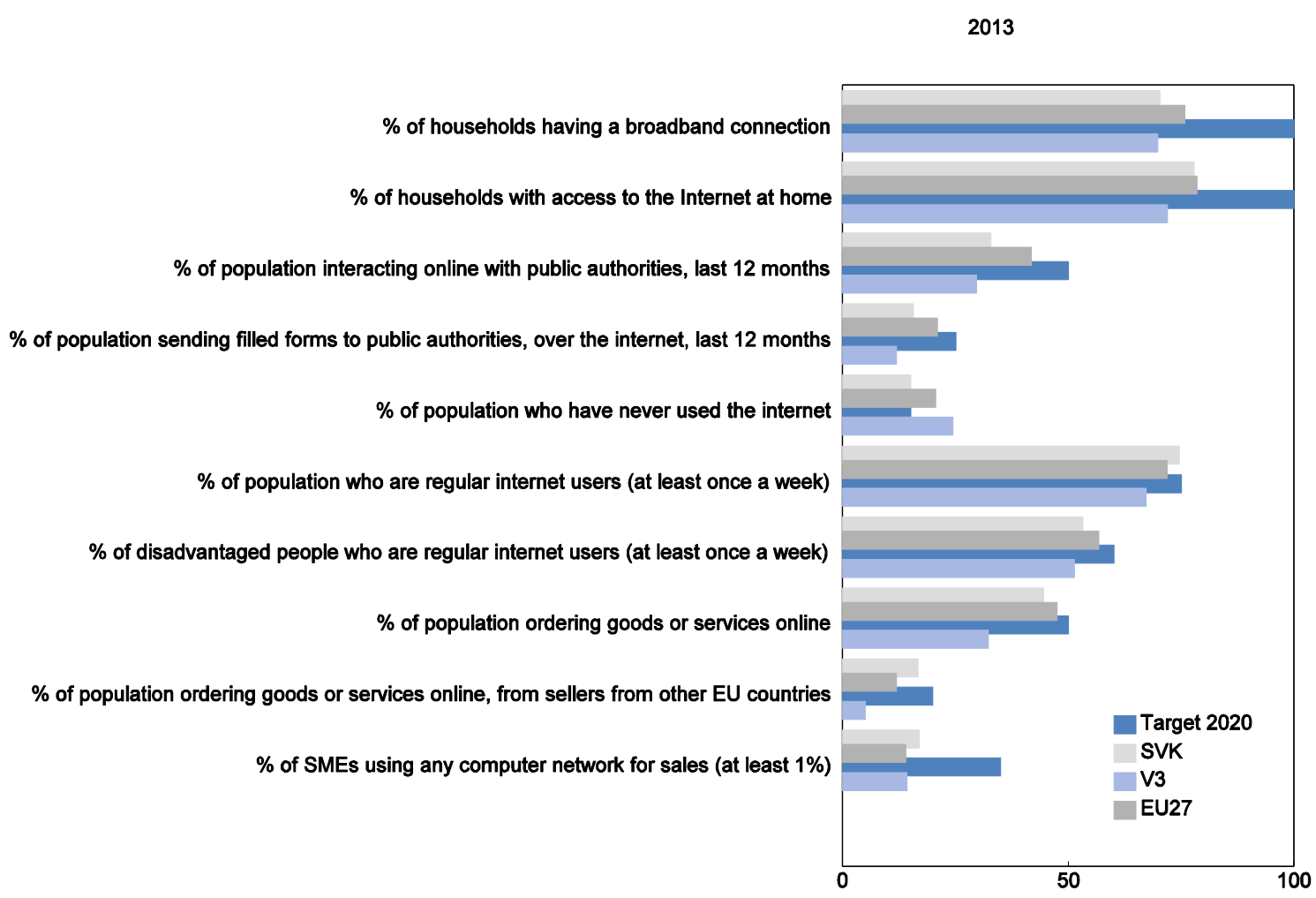

Source: EC Digital Agenda Scoreboard Key Indicators.

\section{Improving human resource management}

Modernisation should embrace reforms to human resource management. Slovakia is characterised by one of the highest turnover of civil servants across OECD countries, including at the junior level (Figure 10, Panel A), in part as a result of the electoral cycle. High turnover reduces the incentive for skill and qualification accumulation and undermines the analytical, strategic and operational capabilities within the government. These problems are aggravated by a low use of strategic human resource practices such as planning, performance assessment and predictable career paths (Figure 10, Panels B and C). Ongoing administrative reform efforts seek to address these problems and key human resource responsibilities were centralised at the Government Office at the end of 2013. To be fully effective, this needs to be accompanied by an amendment to the Act on Civil Service, to increase the independence of the public service, along with merit-based, transparent rules for career growth and higher remuneration. 
Figure 10. Human resource management needs to be improved

A. Turnover of civil servants with a government change Level at least some turn-over ( $1=$ highest staff) ${ }^{1}$ in 2010

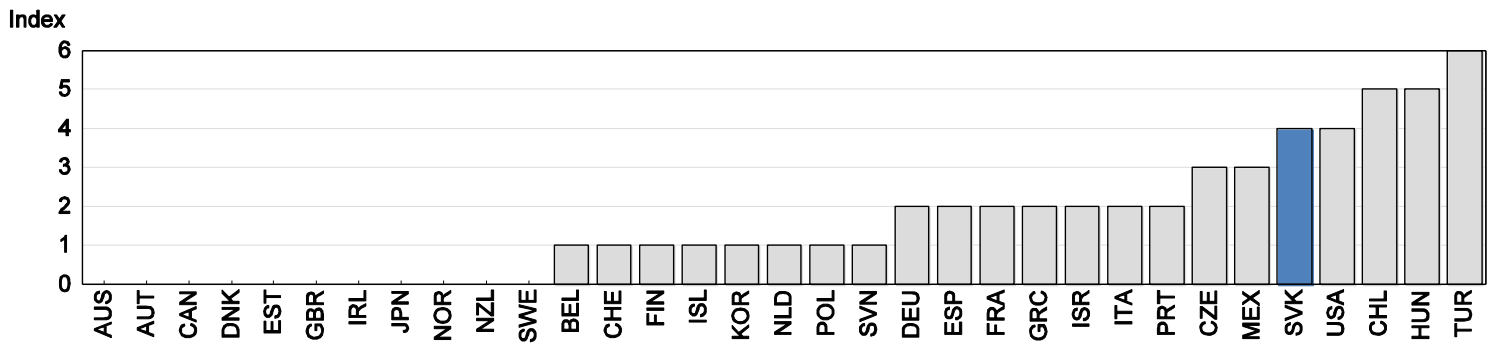

B. Use of separate human resource management practices for senior civil servants Scale 0 to 1 (highly differentiated) in 2010

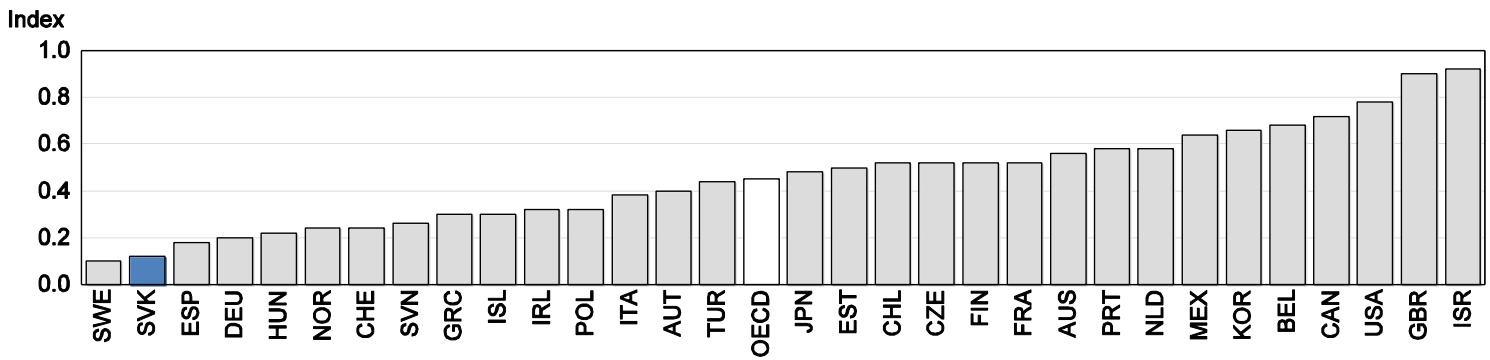

C. Utilisation of strategic human resource management in central government

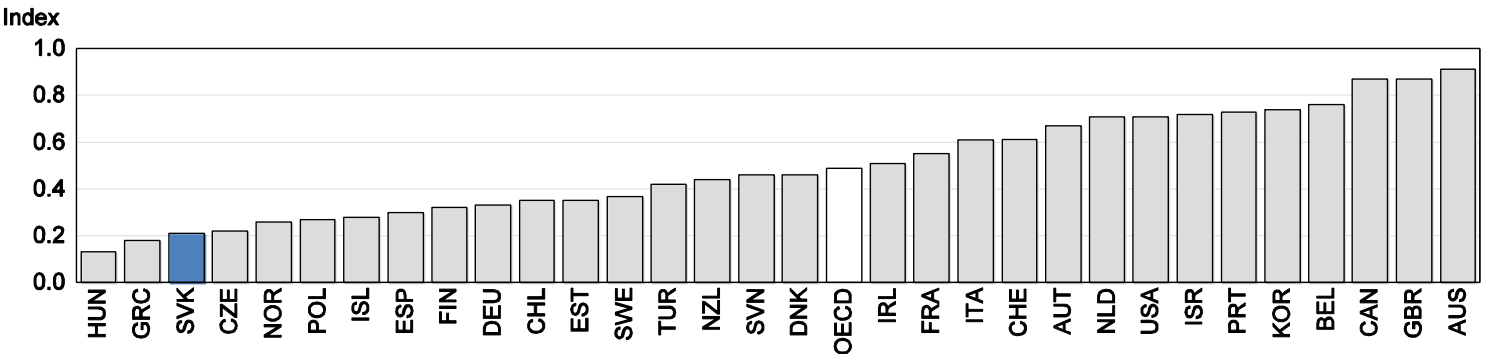

1. The bar shows to what extent there is a change of positions at different levels of civil servants when the government changes. The level ( $y$-axis) ranges from 1 (most senior, i.e. highest level of career in civil services) to 6 (lowest). In the countries with no turnover, the first eleven countries in the figure, a change of government does not directly affect the employment of staff of public servants. The small number of public servants employed in Ministerial offices on an event-based contract, with the event triggering the termination of their contract being the conclusion of their relevant Minster's term in office is ignored. Data for Luxembourg does not exist and data on turnover in level 5 and 6 are not available for all countries.

Source: OECD (2011), Government at a Glance.

\section{The quality of public service is undermined by corruption}

Slovakia is afflicted with a high degree of corruption, which raise costs and reduces the quality of public services. For example, according to a survey by Eurobarometer, $86 \%$ of respondents in Slovakia agreed that there is corruption in public institutions, which is well above the European average (EC, 2013b). Slovakia is among worst OECD performers in the Transparency International Corruption Perception Index (2013). Corruption is perceived as particularly high in the health sector, but also in the central government and, most worryingly, in the judiciary and law enforcement systems (Figure 11, Panel A). Slovakia also scores the worst in the public procurement assessment by EBRD. Indeed, corruption and the perception of corruption undermine trust in government (Figure 11, Panel B). 
Figure 11. Extent of bribery and corruption perception in selected areas

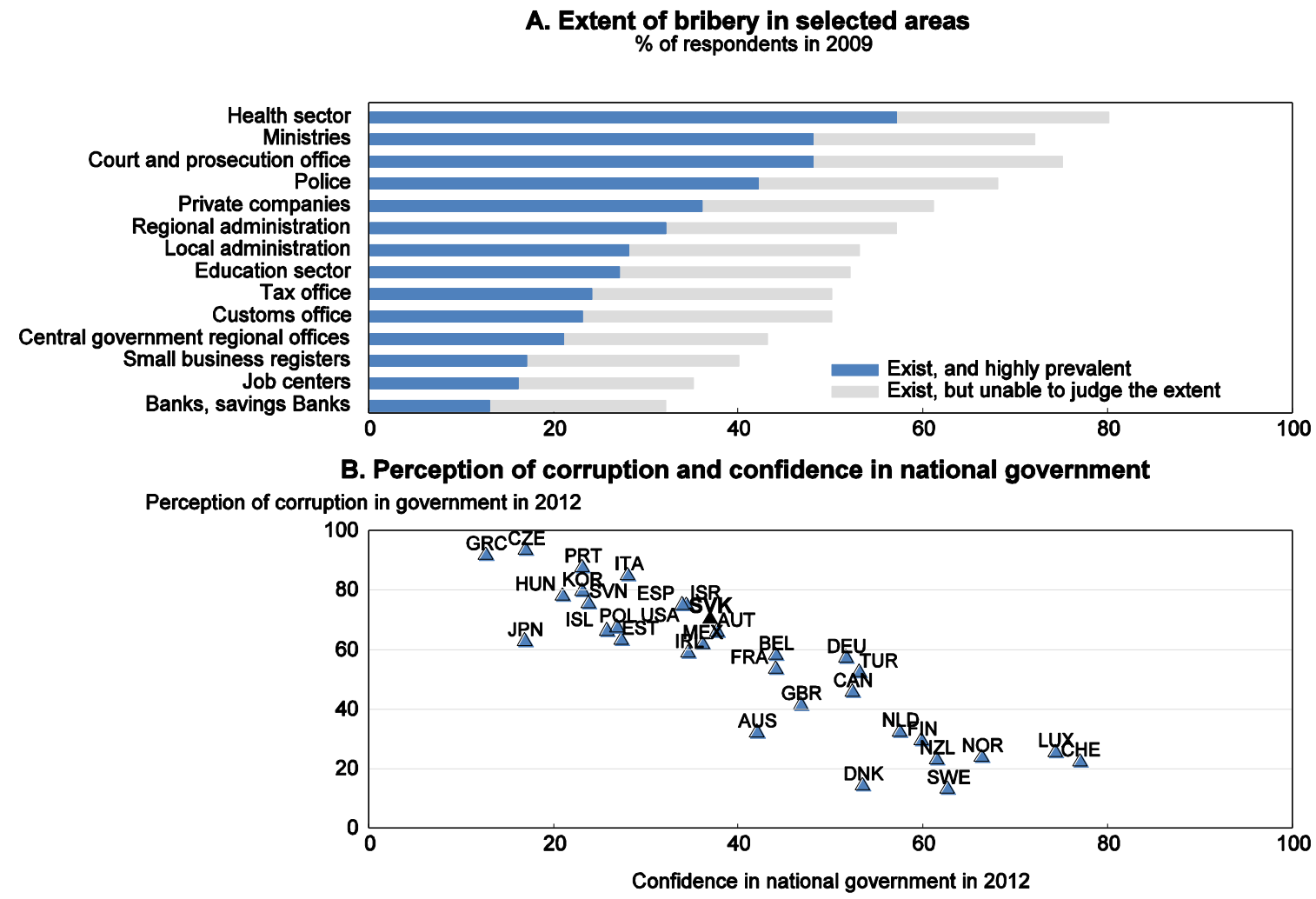

Source: Transparency International Slovensko; World Economic Forum (2014), Global Competitiveness Index Database.

A comprehensive strategic national plan for fighting corruption was adopted in August 2011 as an amendment of an earlier strategic document. The implementation evaluation prepared in 2014 showed that close to $80 \%$ of planned legislative, institutional and operational measures have been implemented by key institutions. The greatest progress has been achieved in the areas of defining clear criteria for issuing licences, franchises, permits, loans and state subsidies, that limit discretion when making such decisions at all levels of the government. Increased transparency has also been introduced in the area of public procurement, though this work is not complete (see above). Also, a code of ethics for civil servants was adopted in April 2013. Several practical solutions for encouraging and protecting whistle blowers have introduced, including an anti-corruption hotline. No assessment of the success of the strategic plan is yet available, and investigations of high-profile political corruption cases, have not been completed despite clear public concern. The degree of forward momentum on anticorruption efforts is thus difficult to judge, but perceptions remain poor, calling for continued ongoing commitment to anti-corruption initiatives.

\section{Economic efficiency: reducing the burden on the private sector}

\section{Improving the efficiency of the tax system}

Consolidation has resulted from revenue as well as expenditure measures, a by-product of which is that the share of the revenues with a higher negative impact on growth, namely direct taxes and social contributions, is increasing. A feature of the tax system is the relatively high reliance on social security charges, in particular charges paid by employers (Figure 12). Also, the time firms spend complying with tax legislation in Slovakia is $15 \%$ greater than the EU average and double that in the best-performing European economies; this is linked to the extremely high number of payments which have to be made in respect of smaller taxes and fees. It is thus important to address both the possible adverse effects of tax on 
businesses and the administrative burden of compliance. In particular, there is evidence of overcomplication, which is likely to be associated with more corruption and less investment (World Bank, 2013).

Figure 12. The tax wedge is high

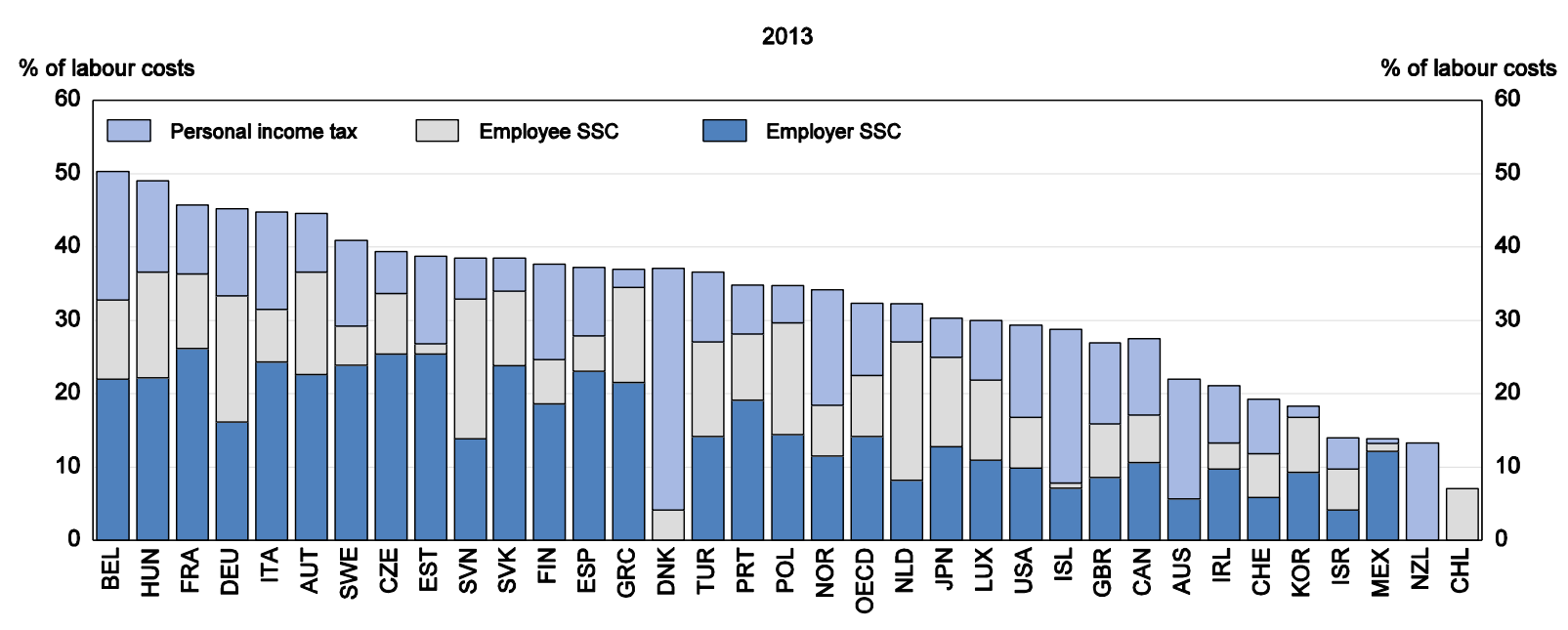

Source: OECD Taxing Wedge Database.

The structure of the system is also distortive in several respects and reforms offer the opportunity for some rebalancing in the tax burden. In particular, distortions in the taxation between different types of employment need to be removed, real estate taxation should be updated by linking the tax base to the market value of property and greater use needs to be made of environmental taxation. Action may, in particular, improve allocational efficiency and assist growth in three areas:

- Self-employed workers have benefited from a lower tax wedge compared to standard workers, which has encouraged firms to avoid social security contributions by substituting self-employed for regular employees. Measures have been taken to make the tax treatment of self-employment income less favourable, which should alleviate the burden on dependent work (EC, 2013a). However, the effective tax on self-employed income is still significantly smaller than that on employee income, so further progress towards neutrality could be made.

- Slovakia has relatively low receipts from recurrent taxes on immovable property ( $1 \frac{1 / 2}{2}$ per cent of total revenues compared with $5 \frac{1}{2}$ per cent for the OECD area). Political obstacles in this area are compounded by institutional problems: in particular, reform would require a better land registry. The authorities are currently considering broadening the taxation by changing the tax base from the number of metres to the value of the property (NRP, 2014).

- Removing non-neutralities with respect to energy taxation, including phasing out tax exemptions on energy would allow taxes on other activities to be reduced. Such exemptions have adverse environmental effects, lead to a misallocation of resources, encourage wasteful consumption and impede investment in clean energy sources (OECD, 2009)

\section{Better tax administration would reduce costs and raise revenues}

The current tax system is also characterised by number of administrative inefficiencies. The "cost of collection ratio", which compares annual administration costs with the total revenue collected, is the highest in the OECD. In particular, Slovakia needs to improve the efficiency of tax collection (Table 2), 
especially with respect to the VAT where revenues fall significantly short of what a standard rate would produce (Figure 13). Bringing the efficiency of VAT revenue collection up to the OECD average would raise revenues equivalent to $0.6 \%$ of GDP. Compliance is low, associated with high VAT compliance costs, in part reflecting its complexity. There is also a problem related to the high proportion of VAT refunds - more than 50\% of gross collections of VAT were refunded in 2010 (OECD, 2013c). This mainly reflects high exports, but there is a need both for systematic processes for granting timely VAT refunds to compliant taxpayers and robust compliance checks for the detection of fraudulent refund claims.

Figure 13. Efficiency of tax collection is low

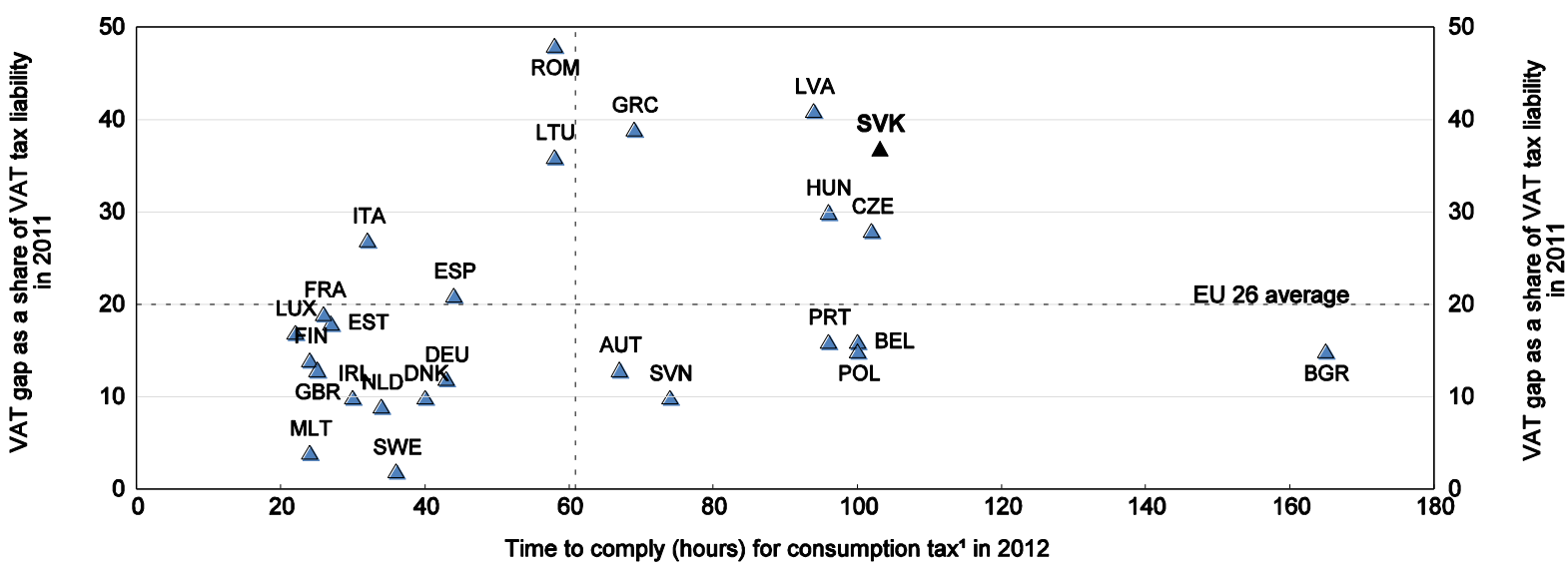

1. Time taken to complete the tax compliance process of preparation, filing and payment of the consumption tax. Time is in hours per year. Consumption tax refers to value added tax or sales tax.

Source: PwC (2014), Paying Taxes 2014 and European Commission (2013), Study to Quantify and Analyse the VAT Gap in the EU27 member states.

Table 2. Costs of tax collection

\begin{tabular}{|c|c|c|c|}
\hline \multirow[b]{2}{*}{$\begin{array}{l}\text { Cost of collection ratio } \\
\text { in } 2011\end{array}$} & \multicolumn{3}{|c|}{ Countries (by level of tax/GDP in 2011)* } \\
\hline & $20-30 \%$ & $30-40 \%$ & Over $40 \%$ \\
\hline $0.61-0.80$ & United States & Iceland & Austria*, Denmark, Finland \\
\hline $1.01-1.20$ & & Hungary, Ireland & France* \\
\hline Over 1.41 & Japan* & Poland*, Slovak Rep.* & Belgium \\
\hline
\end{tabular}

${ }^{*}$ For these countries, SSC are collected by separate agencies, not the revenue body.

Source: OECD, 2013c.

The fragmentation of tax collections has been one of the main reasons for these negative cost and compliance features. On 1 January 2012, the separate Tax and Customs Directorates were amalgamated within a new Financial Directorate and the office network rationalised. Although the integration of social security contribution was planned to be effective from 1 January 2014, it was delayed, and it is uncertain when it will finally happen. Slovakia has also rationalised its network of Tax Offices, reducing 101 Tax Offices to 8 on 1 January 2012, which should improve efficiency of tax system. Reform at the headquarters level also took effect at this time - the Customs Directorate of the Slovak Republic and the Tax Directorate of the Slovak Republic merged into the Financial Directorate of the Slovak Republic. 
At the same time, strategies for managing taxpayer services, hitherto significantly underdeveloped in comparison with other OECD economies, have needed to be upgraded. Electronic services for the basic tax returns filing (for all the major taxes) were extremely under-developed as of end-2011. Arrangements for electronic tax payments have since been improved and a dedicated call centre was established in 2013; but strategies for supporting tax professionals in aspects of tax administration (e.g. with flexible return filing arrangements, online access to client records) are as yet undeveloped, although it should be acknowledged that many countries are deficient in this area. Some steps are currently taken to increase legal certainty for tax payers who have the possibility from September 2014 to ask for information at the Financial Directorate (against fees). Finally, as elsewhere in the public administration, staff attrition rates have been high, at almost double the OECD average, pointing to possibly substantial efficiency gains from better work and job design, and enhanced training and developmental opportunities.

Significant progress has also been made fighting tax evasion. Many measures to fight tax evasion were adopted in the 2012 action plan, focusing mainly on improving VAT collection. They are already bringing important outcomes, the gap between VAT collection in the EU and Slovakia having shrunk considerably from 40\% in 2012 to 36\% in 2013 (NRP, 2014; SP, 2014). New measures include in particular the "tax cobra" scheme to fight major fraud in cooperation with the police and prosecution services and a lottery encouraging customers to request a receipt to promote the payment of tax (NRP, 2014). Efforts should be continued by implementing the third stage of the action plan aimed at improving tax collection, in particular through the introduction of an Electronic Registry of Insolvent Entities (NRP, 2014).

\section{Regulatory and compliance burden on business are excessive}

According to OECD product market regulation (PMR) indicators, Slovakia made good progress in reducing barriers to entrepreneurship over the 2008-13 period. Beginning from a relatively high level, the overall measure of entrepreneurial impediments is now the lowest of all OECD countries (Figure 14, Panel A). However, in some areas the reform impetus has been falling behind and current regulation is far behind best practice (World Bank, 2013). Equally important, weaknesses in the functioning of the public institutions which administer the business environment and ensure law enforcement need to be removed. Slovakia has made little progress in improving the efficiency and transparency of its judicial system and continues to score poorly in international indicators of corruption and e-government (see above).

\section{Making it easier to do business}

The time needed for starting a business is important and Slovakia's ranking has been slipping (World Bank, 2013, Figure 14, Panel B and C). On the positive side, a 'silence is consent' procedure has been introduced, which has significantly simplified the process of opening and operating a business. Another improvement has been the creation of single contact points that can issue or collect all the notifications and licences via the Internet. Under a 'one-stop shop' process, Trade Licensing Offices have been created for trade licences, income tax and health insurance with one application form. However, despite progress, the number of procedures for start-up is still relatively high, and even increasing with respect to establishing a limited liability company (Figure 14, Panel C), indicating red tape. Overall, the Slovak Republic needs to make further efforts to improve the business environment. 
Figure 14. Barriers to entrepreneurship have been reduced

A. OECD Product market regulation (PMR) barriers to entrepreneurship Index scale of 0-6 from least to most restrictive

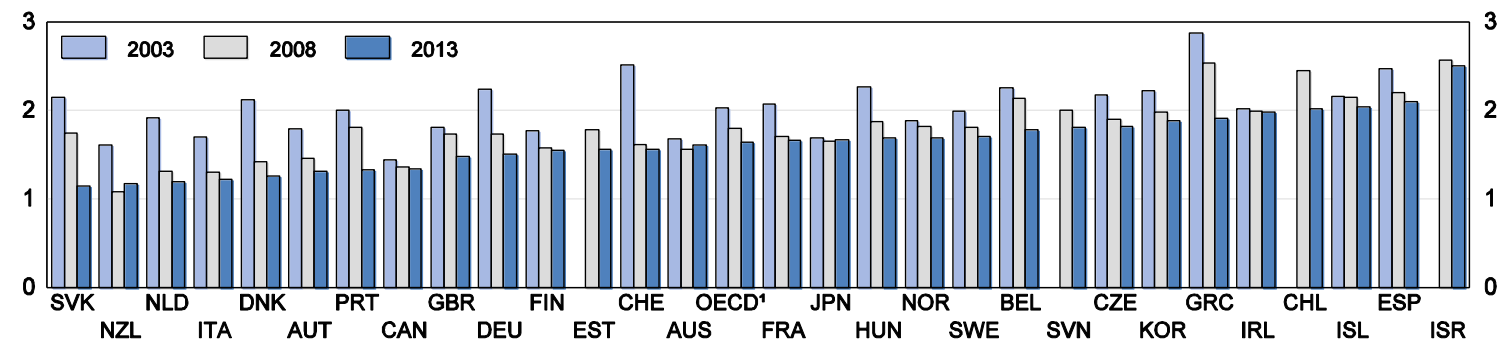

B. Obstacles to starting a business

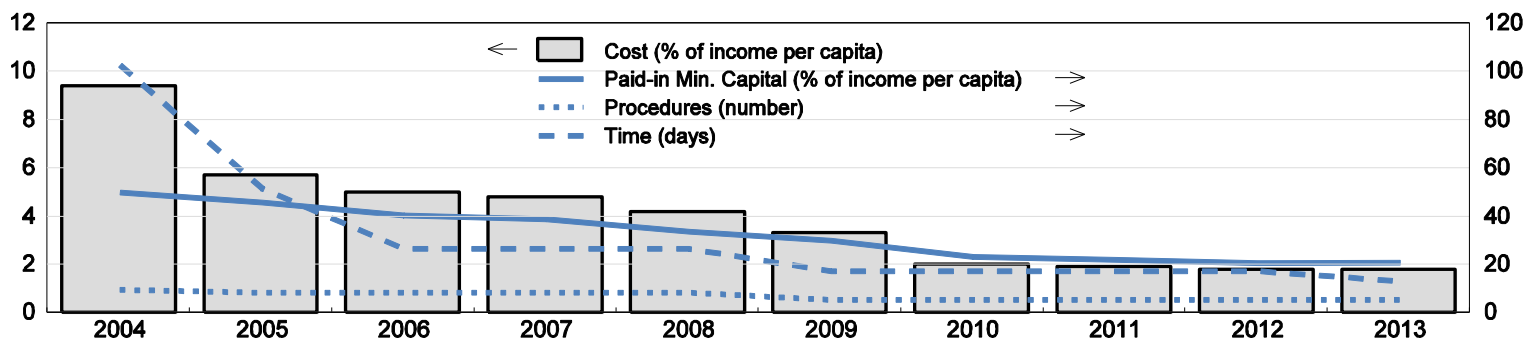

C. Ease of starting a business

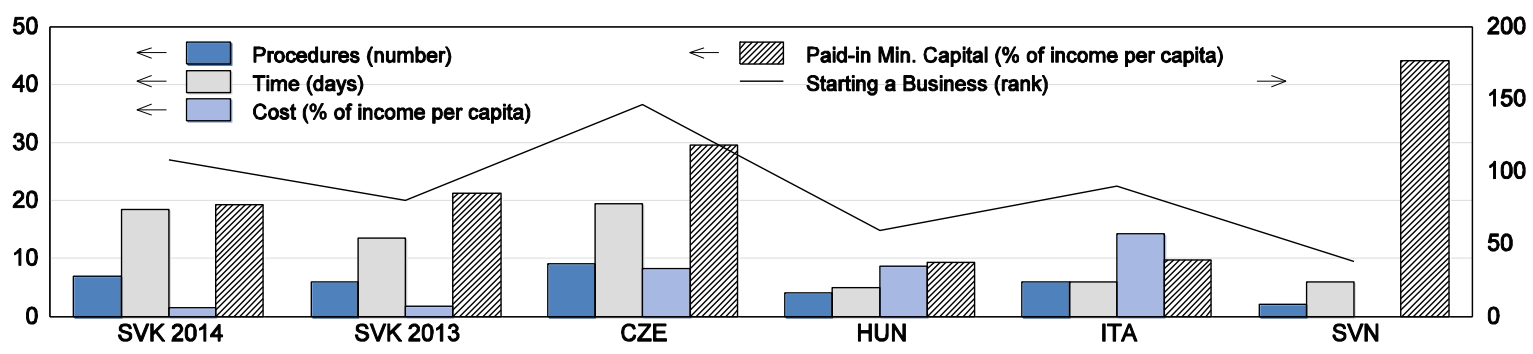

1. OECD refers to the average of the OECD countries for which data are available in 2013.

Source: OECD (2013), Product Market Regulation Indicators and World Bank (2013), Ease of Doing Business.

Since 2008, Slovakia has been responding to EC recommendations aimed at eliminating barriers to SMEs while setting up an "ideal" environment for them. In 2009 and 2010, laws covering a wide range of areas were assessed, including accounting, bankruptcy and restructuring, and market regulation. In June 2011, the Agenda for Better Regulation and the Action Programme for Reducing Administrative Burden for 2007-12 featured a commitment to reducing the administrative burden by $25 \%$ by 2012, a goal with respect to which no ex post assessment is available. According to the more recent information acquired through the latest round of estimating the OECD PMR Indicator, legislation in this area has improved, in particular regarding administrative burden on corporate start-up (OECD, 2013d). Legislation should be closely monitored in respect to how far these welcome reforms are implemented in a way which allows a reduction in the time and costs of closing a business (Figure 15, Panel A), and a simplification of the administrative burden on firms interacting with government (Figure 15, Panel B). 
Figure 15. Regulatory burden on SMEs

\section{A. "Second chance" indicators in 2012}

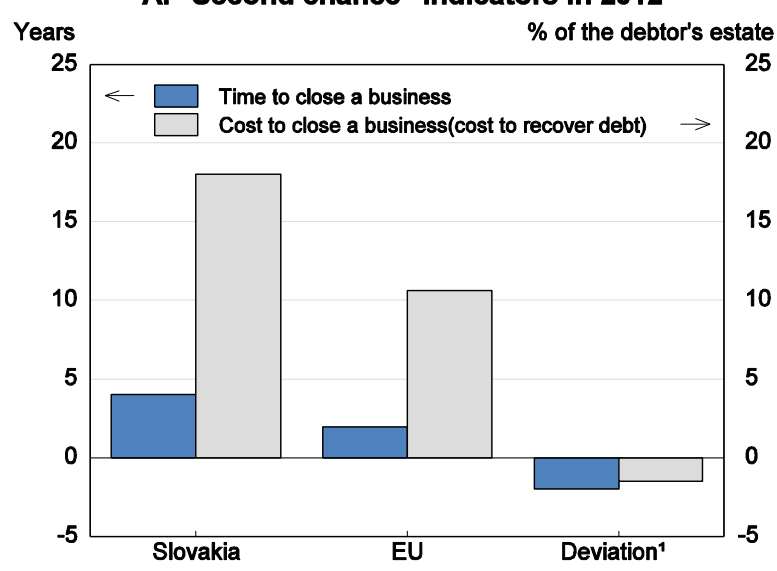

\section{B. Communication and simplification of rules}

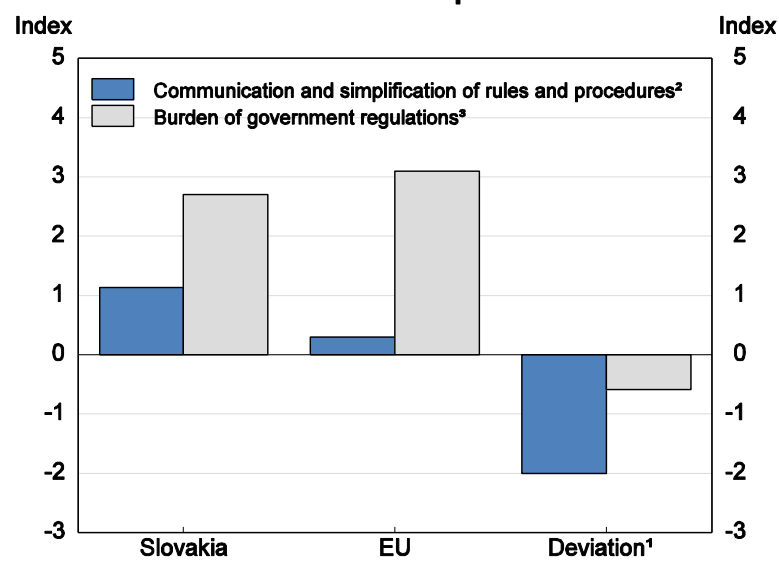

1. Slovakia deviation from EU average.

2. Scale from $0(\max )$ to $6(\mathrm{~min})$. The communication and simplification indicator is calculated using the country's self-reported answers in 2008 .

3. Scale from 1 (burdensome) to 7 (not burdensome). The burden of regulation refers to 2011.

Source: European Commission (2012), SBA Fact Sheets.

The EC identifies a range of tools to ensure the effective implementation of the 'better regulation' principle, including the application of an "SME test" for legislative proposals, the use of SME-specific provisions in legislation to avoid inadequate regulatory/administrative burden on SMEs, and consultation of SME stakeholders (EC, 2012c). However, in Slovakia the regulatory framework has been frequently changed without sufficient analysis of its impact on the private sector via regulatory impact assessments. The processes and the institutions for ensuring the quality of impact assessments throughout the decisionmaking process do not seem to have been adequate to prevent continued excessive regulatory and administrative barriers and until the latter years of the last decade were well away from best practice (Jacobzone et al., 2007). Against this background the rules and institutions of Regulatory Impact Assessment (RIA) had to be re-formulated. A unified methodology was introduced in 2008 and updated in 2010, stipulating the obligation to evaluate the impact of new legislation on 5 areas, including on the business sector (Box 3).

This process is now in need of strengthening: the national reform agenda includes a promise to increase the quality of the legislation creation process, by updating the methodology used for assessing the selective effects of legislative and non-legislative proposals, including the introduction of obligatory consultations with the affected entities as well as obligatory analysis of alternative solutions (NRP, 2014). The authorities could take this opportunity to design the RIA methodology in line with international best practices identified in the review on Regulatory Compliance Cost Assessment (OECD, 2014b). Communicating the results of the RIA is also essential for improving regulatory design (OECD, 2008). Going forward, an independent group of experts which would provide statements on the quality of impact assessments would also contribute to strengthening the quality of regulatory assessment process. The Dutch Actal, the German Normenkontrollrat or the Czech RIA Board can be used as examples. Finally, the RIA process should be under the responsibility of a single central institution which should play a leading role in the implementation of policies, the co-ordination between ministries, the quality control of assessment, the choice of a unified methodology and the implementation of training and assistance to line ministries. 


\section{Box 3. Regulatory impact assessment in Slovakia}

A unified methodology was introduced in 2008 and updated in 2010, stipulating the obligation for evaluating the impact of new legislation on five areas: business, public finance, social area, environment and information society/e-government.

\section{Intergovernmental comments proceedings}

Since 2010, an obligation to provide an Annex has been established where the expected impact in each area is presented. This annex is mainly based on assumptions but is supplemented by deeper analysis in case the initial assessment identifies either a positive or a negative impact. Such an annex is required for all legislative or nonlegislative materials and is discussed in the context of intergovernmental comments proceedings, which is settled prior to the submission to the government session.

The intergovernmental comments proceedings last from 5 to 15 days, depending on urgency and nature of a proposed material. Exceptions are possible if a material is of an informative nature and does not contain a draft decision of government.

\section{Pre-comments proceedings}

Prior to intergovernmental comments proceedings a pre-comments proceedings is performed, which requires submitting the proposed material to four supervising ministries in charge of evaluating the quality and accuracy of the impact analysis. Since 1 September 2011, this step is no longer mandatory but just an option for legislative material.

Regulations resulting from implementation of EU directives are excluded from the pre-comments proceedings.

The pre-comments proceedings last from 5 to 20 days, depending on the urgency.

\section{Impact on business environment}

This includes the type and number of subjects affected, the range of costs and contributions, the amount of administrative costs, the effects on the functioning of markets, and the socio-economic impact. This has contributed to improve the efficiency of regulation and reduce the negative impacts of regulation on the business environment.

\section{Further progress needs to be made in liberalising services}

Many of the regulatory barriers to entry into services, as defined under the EU Services Directive (in force since end-2009), have been abolished. ${ }^{5}$ Fees charged by the engineering and architecture professions have been deregulated, for instance. However, in some areas, there is a trend towards tighter regulation. For example, the number of years of practice for the legal profession has increased, and in the retail sector there is still a maximum limit on the value of the discount for products. Overall, as measured by the OECD PMR indicator for professional and retail services, Slovakia still has much progress to make (Figure 16, Panel A). Some of the gains will be locked in under the EU Services Directive. According to EU calculations, full implementation of the services directive is projected to yield benefits of $0.75 \%$ in terms of GDP, a figure which is quite close to the EU average gain (Figure 16, Panel B) (EC, 2012d). The gains would be somewhat larger if the Slovak Republic were more ambitious and move to the level of restrictions of the five best countries in the EU per sector which is de facto close to a full elimination of barriers; that would bring additional gains amounting to almost $0.35 \%$.

5. The scope of the Act includes: travel agencies; hotels; construction/building companies; real estate agents; tourist guides; small retail shops; restaurants; large retailers; certification service in the area of construction; crafts businesses in construction sector; engineers; tax advisers; architects; legal services; accountants. 
Figure 16. Services liberalisation

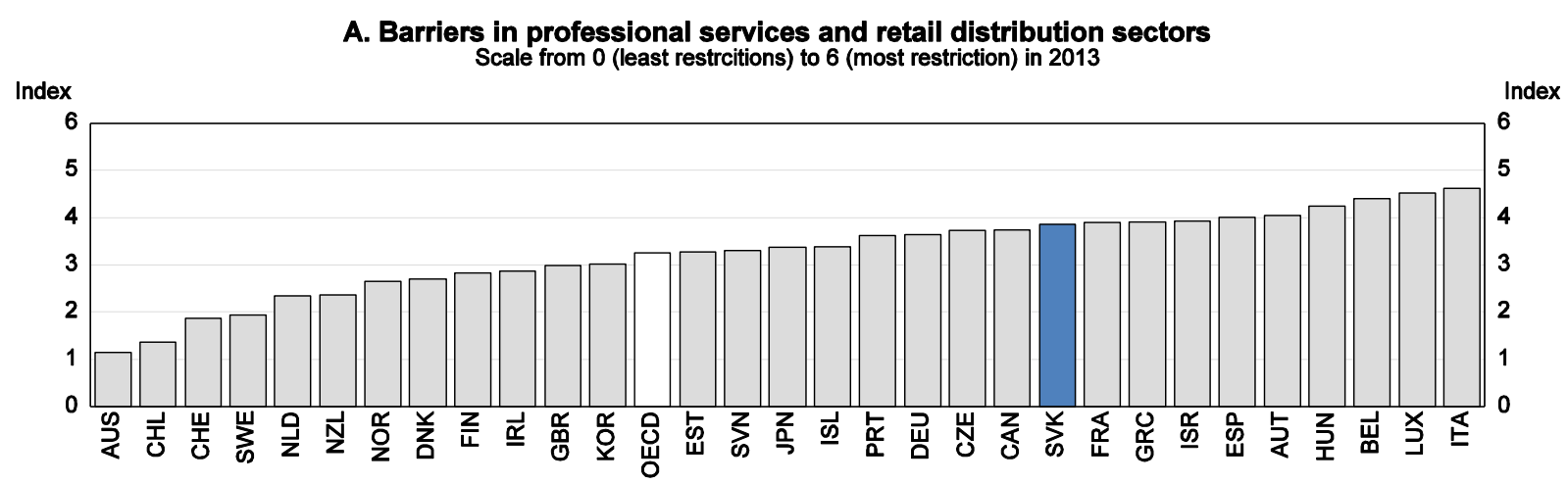

\section{B. Services liberalisation}

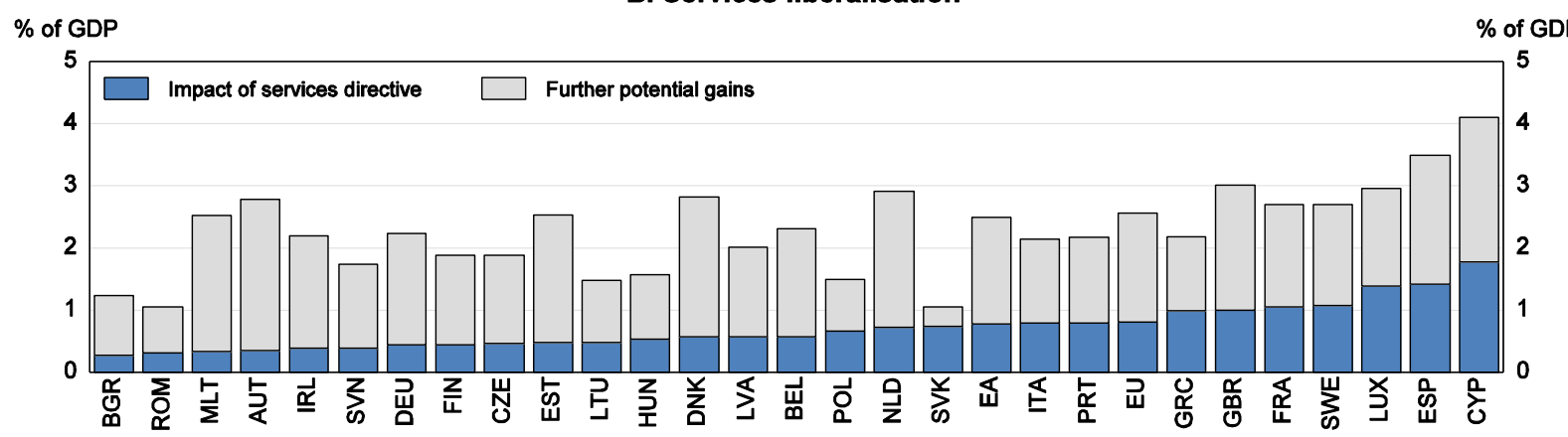

Source: OECD (2013), Product Market Regulation Database and EU Single Market Regulated Professions Database.

\section{An inefficient justice system is holding back the economy}

The judicial process in Slovakia is slow, burdensome and unreliable, limiting access to judicial settlement, complicating business activity and adding to business costs (Figure 17). According to the World Economic Forum indicators, Slovakia ranks in the bottom $2 \%$ of surveyed countries with respect to the efficiency of the legal system in settling disputes and in challenging regulations (WEF, 2013). The time required resolving the bankruptcy procedure is four years, much higher than the OECD average and higher than would be required for the system to act as filter for ensuring the survival of economically efficient companies, or reallocating the resources of inefficient ones (World Bank, 2013). Contract enforcement takes 545 days, costs $30 \%$ of the value of the claim and requires 32 procedures (ibid.). Securities regulations, company law and court rules of evidence also point to a weaker degree of investor protection than the OECD average.

The judicial system is also perceived as globally one of the least independent (WEF, 2013), which discourages the pursuit of justice. Where cases are pursued, justice is rather slow. While it allocates around $0.2 \%$ of GDP to the courts' budget, similar to Switzerland and the Czech Republic, the average trial duration is 2.7 times longer and the cost of trial as a percentage of the value of the claim is among the highest in the OECD and several times higher than in best performing countries (Figure 18). Thus the judicial system needs streamlining if the modernising of the public administration is to have full effect on the business environment. 
Figure 17. Indicators of judicial process

\section{A. Time needed to resolve bankruptcy cases' in 2013}
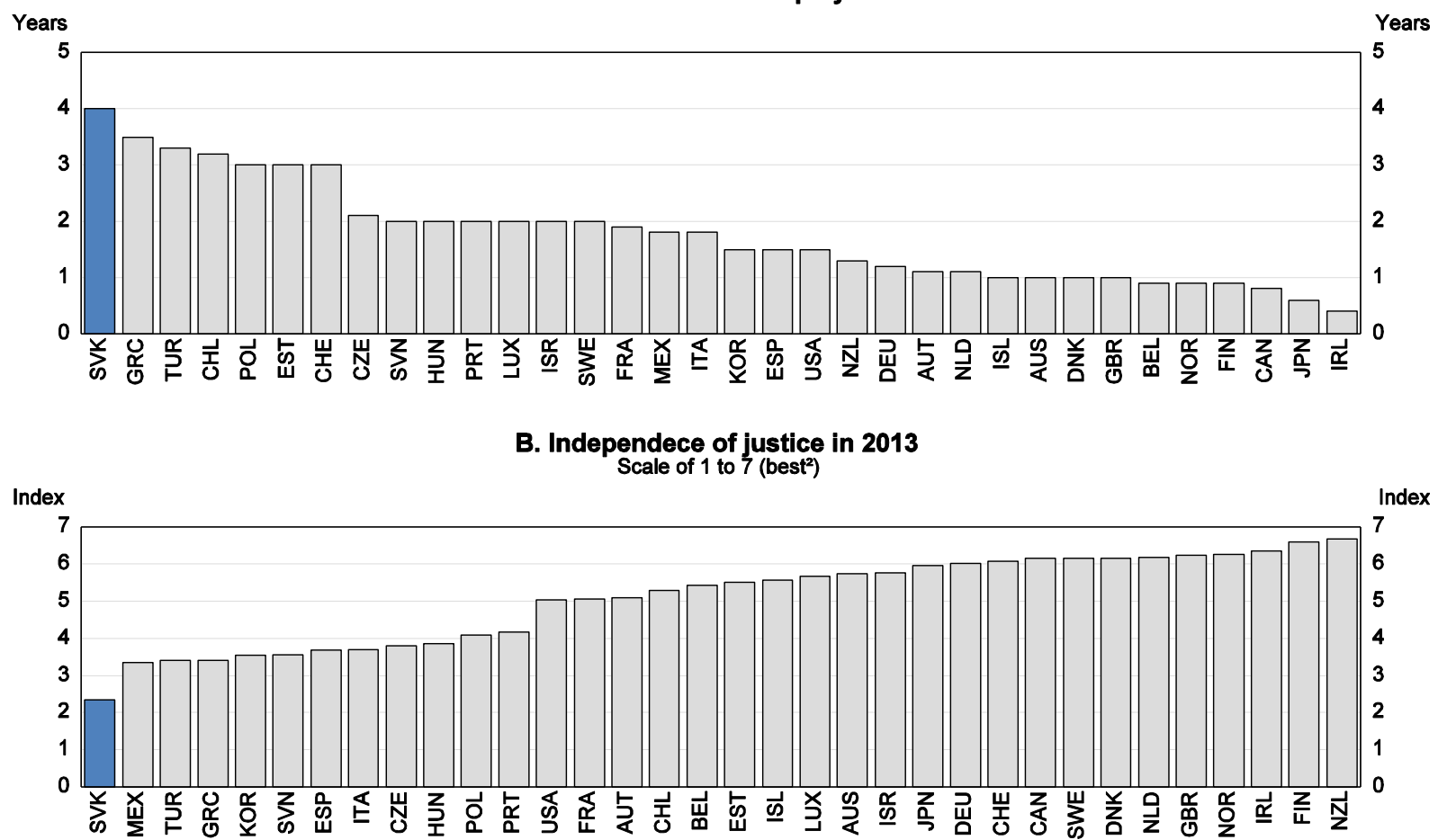

1. Time to resolve insolvency is the number of years from the filing for insolvency in court until the resolution of distressed assets.

2. The highest value means better perception. Source: World Economic Forum and World Bank Doing Business (2013).

Figure 18. ICT justice budget and judicial performance

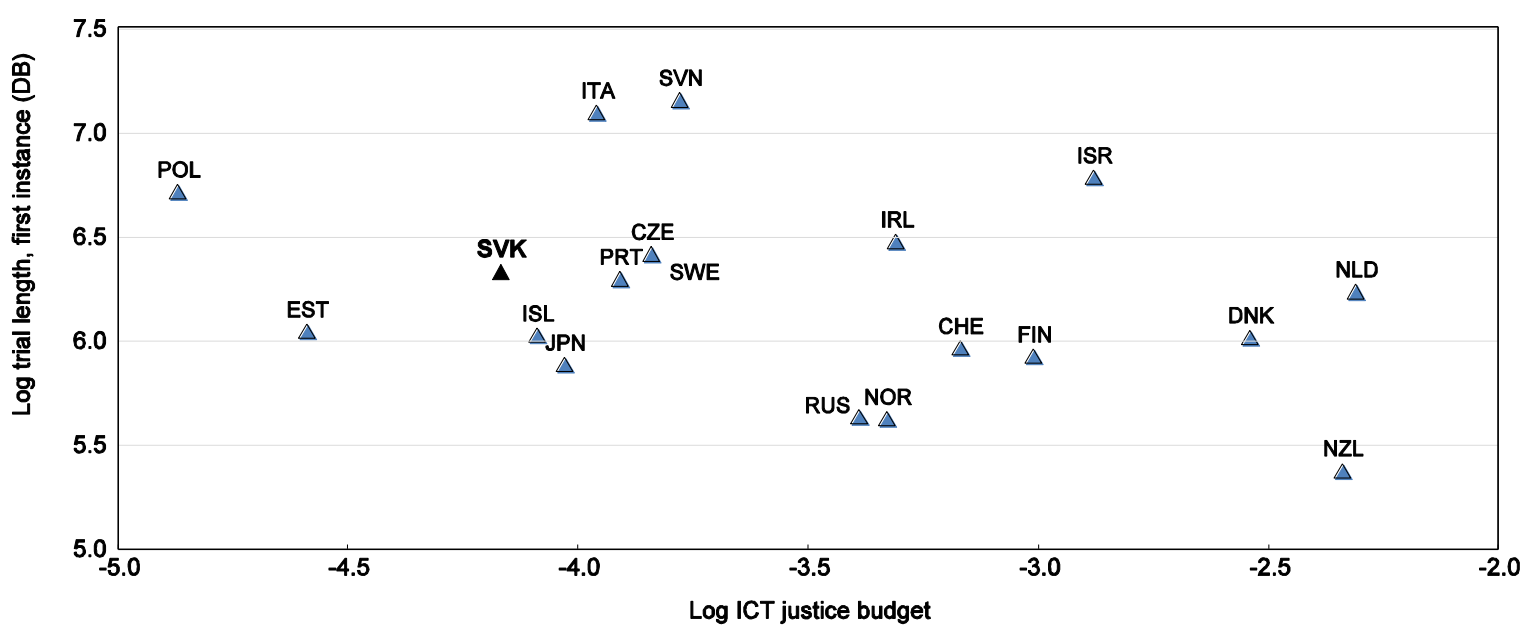

Note: The share of the justice budget allocated to informatisation (ICT justice budget) is computed as the ratio of annual public budget allocated to computerisation to the public budget allocated to the functioning of the courts (excluding financial resources devoted to legal aid and public prosecution services). Trial length is taken from the World Bank Doing Business. The share of budget allocated to ICT may under-estimate the effective amount of resources devoted to ICT for it does not include co-financing by supranational bodies (e.g. EU structural funds).

Source: OECD (2013), OECD Economic Policy Papers No. 5, "Judicial performance and its determinants: a cross-country perspective". 
Progress towards reform is slow. The Slovak Republic has recently improved its insolvency processes and contract enforcement, intended to simplify and speed up proceedings and limit obstructive tactics by parties to a case. However, the court infrastructure needs modernising, and the judiciary needs to be more transparent. To help achieve this, greater priority could be given to policies that increase the capacity of the system to meet the demand for justice, such as computerisation, which is currently among the lowest across the OECD, the adoption of more advanced case-flow management techniques and the enhancement of the degree of court specialisation. Judicial appointments also need to be made completely transparent. As part of the strategic policy framework, significant reforms are planned to modernise the judiciary, to eliminate delays in court procedures and to increase the quality of court decisions and court staff, and to promote alternative dispute resolution mechanisms. So far most of the proposed legislative changes have not been fulfilled, but it is important that the target deadlines through to end-2016 be met.

\section{Recommendations for reforming the public sector}

Key recommendations

\section{Refining fiscal consolidation}

- Implement multi-annual binding spending ceilings to reinforce budget discipline in upturns.

- Continue strengthening revenue collection, and increase taxation on property and environmentally harmful activities.

For a more efficient and effective public administration and regulatory environment for doing business

- Establish better human resource management, modernise public administration and strengthen coordination and collaboration across government.

- $\quad$ Reduce regulation in professional services and retail trade, strengthen regulatory impact assessment.

- Strengthen the efficiency and independence of the judicial system.

- Ensure that public procurement achieves the best value for money and continue with measures fighting corruption, inter alia by guaranteeing better transparency.

\section{For a better use of EU funds}

- $\quad$ Streamline administrative procedures and strengthen capacities to manage EU funds.

\section{Further recommendations}

\section{Ensuring efficiency of public spending}

- Re-prioritise spending towards investment.

- $\quad$ Modernise management, via performance budgeting, e-government, and more open public procurement.

\section{Refining the role of state in the economy}

- Improve the efficiency of tax administration

- Reduce bureaucratic costs and delays and make regulations more business-friendly.

- Increase judicial capacity in particular through investment in IT systems. 


\section{Bibliography}

Buček, J. (2011), "Building of regional self-government in Slovakia: the first decade", Geographical Journal, 63 1, 3-27.

CKO (2012), Strategická správa Slovenskej republiky, Centrálny koordinačný orgán, MDVRR SR.

CKO (2013), Analýza administratívnych kapacít subjektov zapojených do implementácie, certifikácie a vládneho auditu štrukturálnych fondov a Kohézneho fondu na programové obdobie 2007 - 2013 za obdobie od 01. 07. 2012 do 30. 06. 2013, Centrálny Koordinačný Orgán, Úrad Vlády SR.

Erawatch (2014), Platform on Research and Innovation Policies and Systems, available at erawatch.jrc.ec.europa.eu/erawatch/opencms/information/country_pages/sk/country?section=Overvi ew\&subsection=Overview.

European Commission (2011), What evolution can be identified in the organisations managing EU funding, particularly due to simplification efforts pursued by the Commission in 2008, 2009 and 2010?, DG for internal policies Report, EC, Brussels.

European Commission (2012a), 2012 Ageing Report: Economic and budgetary projections for the EU27 Member States (2010-2060), EC, Brussels.

European Commission (2012b), Position of the Commission Services on the development of the Partnership Agreement and programmes in Slovakia for the period 2014-2020, EC, Brussels.

European Commission (2012c), Enterprise and Industry: SBA Fact Sheet 2012, Slovakia, EC, Brussels.

European Commission (2012d), "The economic impact of the Services Directive: a first assessment following implementation", DG CFIN, EC, Brussels

European Commission (2013a), "Assessment of the 2013 national reform programme and stability programme for Slovakia”, Commission Staff Working Documents COM(2013)373 final, EC, Brussels.

European Commission (2013b), Flash Eurobarometer Report, European Commission, EC, Brussels.

European commission (2013c), Study to Quantify and analyse the VAT Gap in the EU-27 Member States, Center for Social and Economic Research Network Report

European Commission (2014a), “Recommendation for a Council Recommendation on Slovakia's 2014 national reform programme and delivering a Council opinion on Slovakia's 2014 stability programme",SWD(2014) 426 final, EC, Brussels.

European Commission (2014b), JRC Scientific and Policy Reports Erawatch Country reports 2012: Slovak Republic, EC, Brussels. 
Fernas, A. (2013), Transparency Case Study: Public Procurement in the Slovak Republic, available at http://sunlightfoundation.com/blog/2013/08/12/case-study-public-procurement-in-the-slovakrepublic.

Horvath, M. and L. Ódor (2009), "Making Fiscal Commitments Credible”, National Bank of Slovakia, Research Department, Working and Discussion Paper, No. 1006.

IMF (2007), Manual on Fiscal Transparency, International Monetary Fund, Washington, DC.

Jacobzone, S., C. Choi and C. Miguet (2007), "Indicators of Regulatory Management Systems", Working Papers on Public Governance 2007/4, OECD Publishing, doi:10.1787/112082475604.

NRP (2014), National Reform Programme of the Slovak Republic, April (NRP), Slovak Government, Government Office.

OECD (2008), Building an Institutional Framework for Regulatory Impact Analysis (RIA): Guidance for Policy Makers, OECD Publishing.

OECD (2009), OECD Economic Surveys: Slovakia, OECD Publishing.

OECD (2011), Government at Glance 2011, OECD Publishing.

OECD (2012a), Economic Surveys: Slovak Republic, OECD Publishing.

OECD (2012b), Council Recommendation on Principles for Public Governance of Public-Private Partnerships, OECD Publishing.

OECD (2012c) Progress Made in Implementing the OECD Recommendation on Enhancing Integrity in Public Procurement, OECD Publishing.

OECD (2013a), Education at a Glance 2013, OECD Publishing.

OECD (2013b), OECD Skills Outlook 2013: First Results from the Survey of Adult Skills, OECD Publishing.

OECD (2013c) Tax Administration 2013: Comparative Information on OECD and Other Advanced and Emerging Economies.

OECD (2013d), Product Market Regulation, OECD Publishing.

OECD (2013e), Government at a Glance, OECD Publishing.

OECD, (2013f), "Judicial performance and its determinants", Economic Policy Papers No. 5, OECD Publishing.

OECD (2014a), Slovak Republic: Developing a Sustainable Strategic Framework for Public Administration Reform, OECD Publishing.

OECD (2014b), OECD Regulatory Compliance Cost Assessment Guidance, OECD Publishing.

OECD (2014c), OECD Economic Surveys: Slovakia, OECD Publishing. 
OPKE, (2011), Slovakia to the First League, Office of the Plenipotentiary for Knowledge Economy.

PwC (2014), Paying taxes 2014, PricewaterhouseCoopers, the World Bank and International Finance Corporation, available on www.pwc.com/payingtaxes.

Šiškovič Matej (2013), Educational Policy Institute -better analysis for better policy, amcham connection, September/October, www.amcham.sk/download.pl?hash...ID=3643.

Slovak Government, Government Office (2013), Strategic Framework of Public Administration Reform in the Slovak Republic.

SP (2014), Stability Programme of the Slovak Republic for 2014-2017, Ministry of Finance of the Slovak Republic.

Sutherland, D., R. Price, I. Joumard and C. Nicq (2007), "Performance and Indicators for Public Spending Efficiency in Primary and Secondary Education", Economics Department Working Papers No. 546. OECD Publishing.

Sutherland D., S. Araujo, B. Egert and T. Kozluk (2009), "Infrastructure investment: Links to Growth and the role of public Policies", Economic Department Working Papers 546, OECD Publishing.

The State of Open Data (2012), www2012.wwwconference.org/proceedings/nocompanion/wwwwebsci2012_braunschweig.pdf.

Transparency International (2013), International Corruption Index 2013.

United Nations (2012), United Nations eGovernment Survey 2012.

WEF (2013), Global Competitiveness Report 2013-2014, World Economic Forum, Geneva. Country profile: Slovak Republic http://www3.weforum.org/docs/GCR2013-14/SlovakRepublic.pdf

World Bank (2013), Doing Business 2014: Understanding Regulations for Small and Medium-Size Enterprises. Washington, DC: World Bank Group. Country profile: Slovak Republic: Slovak Republic, http://www.doingbusiness.org/data/exploreeconomies/slovakia/ 


\section{WORKING PAPERS}

The full series of Economics Department Working Papers can be consulted at www.oecd.org/eco/workingpapers

1211. Spurring growth in lagging regions in Slovak Republic

(April 2015) by Lilas Demmou, Gabriel Machlica, Martin Haluš

1210. Skill mismatch and public policy in OECD countries

(April 2015) by Müge Adalet McGowan and Dan Andrews

1209. Labour market mismatch and labour productivity: evidence from PIAAC data

(April 2015) by Müge Adalet McGowan and Dan Andrews

1208. Maintaining an efficient and equitable housing market in Belgium

(April 2015) by Sanne Zwart

1207. Determinants of the low female labour force participation in India

(April 2015) by Piritta Sorsa, Jan Mares, Mathilde Didier, Caio Guimaraes, Marie Rabate,

Gen Tang and Annamaria Tuske

1206. Strengthening skill use and school-to-work transitions in the Czech Republic

(April 2015) by Sónia Araújo and Petr Malecek

1205. Taking care of the unloved: reforming the tax on immovable property

(April 2015) by Hansjörg Blöchliger

1204. Taxation and investment in Colombia

(April 2015) by Sarah Perret and Bert Brys

1203. Efficiency and contestability in the Colombian banking system

(April 2015) by Christian Daude and Julien Pascal

1202. Fiscal decentralisation in Colombia: new evidence regarding sustainability, risk sharing and "fiscal fatigue"

(April 2015) by Guillaume Bousquet, Christian Daude and Christine de la Maisonneuve

1201. Effects of economic policies on microeconomic stability

(April 2015) by Boris Cournède, Paula Garda and Volker Ziemann

1200. The 2013 update of the OECD's database on product market regulation - policy insights for $O E C D$ and non-OECD countries

(April 2015) by Isabell Koske, Isabelle Wanner, Rosamaria Bitetti and Omar Barbiero

1199. Improving taxes and transfers in Australia

(April 2015) by Philip Hemmings and Annamaria Tuske

1198. Federal-state relations in Australia

(April 2015) by Vassiliki Koutsogeorgopoulou and Annamaria Tuske 
1197. Sharing the fruits of growth with all Mexicans

(April 2015) by Eduardo Olaberriá and Valéry Dugain

1196. What makes Mexicans happy?

(April 2015) by Valéry Dugain and Eduardo Olaberriá

1195. Improving the labour market integration of immigrants in Belgium

(March 2015) by Álvaro Pina, Vincent Corluy and Gerlinde Verbist

1194. Raising the potential of the domestically oriented sector in Germany

(March 2015) by André Eid and Andrés Hutfilter

1193. Improving transport infrastructure in Russia

(March 2015) by Alexander Kolik, Artur Radziwill and Natalia Turdyeva

1192. Improving the business climate in Russia

(March 2015) by Arthur Radziwill and Yana Vaziakova

1191. Determinants of female entrepreneurship in India

(March 2015) by Arnaud Daymard

1190. The changing role of the exchange rate for macroeconomic adjustment

(March 2015) by Patrice Ollivaud, Elena Rusticelli and Cyrille Schwellnus

1189. Boosting productivity in Russia: skills, education and innovation

(March 2015) by Lilas Demmou and Andreas Wörgötter

1188. Boosting growth and reducing informality in Mexico

(March 2015) by Sean Dougherty

1187. The conduct of monetary policy in the future: instrument use

(March 2015) by Kei-Ichiro Inaba, Rory O'Farrell, Łukasz Rawdanowicz and Ane Kathrine Christensen

1186. A constant market share analysis of Spanish goods

(February 2015) by Alberto Gonzalez Pandiella

1185. Raising the economic participation of women in India - a new growth engine?

(February 2015) by Piritta Sorsa

1184. Improving health outcomes and health care in India

(January 2015) by Isabelle Joumard and Ankit Kumar

1183. Challenges and opportunities of India's manufacturing sector

(January 2015) by Isabelle Joumard, Urban Sila and Hermes Morgavi

1182. The heterogeneity of product market regulations

(December 2014) by Jean-Marc Fournier 